\title{
EDUCAÇÃO SUPERIORH
}

\section{Experiências e (re)significações em tempos de pandemia da COVID-19}

Guilherme Mendes Tomaz dos Santos

Júlio Paulo Cabral dos Reis [Organizadores] 


\section{EDUCAÇÃO SUPERIORH}

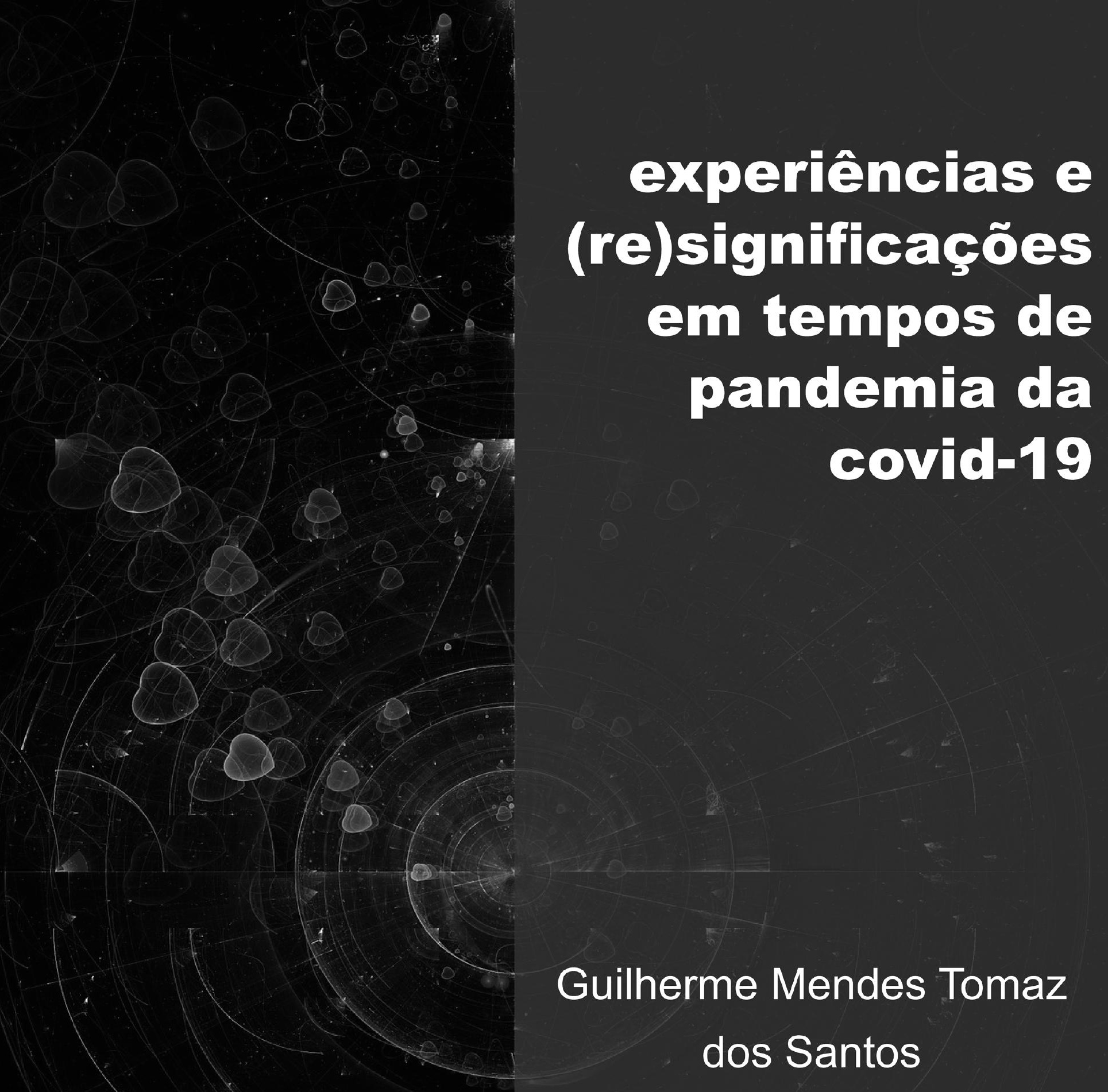

Júlio Paulo Cabral dos Reis

[Organizadores] 


\section{1. ${ }^{a}$ Edição - Copyrights do texto - Autores e Autoras}

Direitos de Edição Reservados à Editora Terried

O conteúdo dos capítulos apresentados nesta obra são de inteira responsabilidade d@s autor@s, não representando necessariamente a opinião da Editora.

Permitimos a reprodução parcial ou total desta obra, considerado que seja citada a fonte e a autoria, além de respeitar a Licença Creative Commons indicada.

\section{Conselho Editorial}

Adilson Cristiano Habowski

Anísio Batista Pereira

Adilson Tadeu Basquerote Silva

Alexandre Carvalho de Andrade

Cristiano Cunha Costa

Emily Verônica Rosa da Silva Feijó

Fernanda Monteiro Barreto Camargo

Fredi dos Santos Bento

Fabiano Custódio de Oliveira

Guilherme Mendes Tomaz dos Santos

Leandro Antônio dos Santos

Lourenço Resende da Costa

\section{Diagramação:}

Editora TerriED

Revisão:

dos/as autores/as.

imagem capa:

www.freepik.com 


\section{Dados de Catalogação na Publicação (CIP)}

Educação Superior: experiências e

(re)significações em tempos de pandemia da covid-19 [livro eletrônico] / organização

Guilherme Mendes Tomaz dos Santos; Júlio Paulo

Cabral dos Reis. -- Alegrete, RS : TerriED

Editora, 2021.

$\mathrm{PDF}$

ISBN $978-65-995948-3-0$

1. Educação. 2. Ensino.

CDD -370

CDU-21-37/49

Índices para catálogo sistemático:

1. Educação 370. 2. Ensino 37.

\section{TERRIED}

(www) www.terried.com

Dcontato@terried.com

(0) @editora_terried

(f) leditoraterried 


\section{APRESENTAÇÃo}

Em tempos de pandemia da COVID-19, estamos sendo, diariamente, desafiados a nos (re)organizarmos enquanto seres humanos e profissionais das diferentes áreas do conhecimento. A Educação, por sua vez, não está distante de tal realidade. O contexto educacional teve que, rapidamente, desde março de 2020, adaptar-se por meio dos processos de ensino-aprendizagem que pudessem efetivar e garantir a permanência dos estudantes em sua formação escolar e acadêmica. E, uma de tais alternativas, foi a adoção de modo incessante e protagonista das tecnologias digitais como recursos didático-pedagógicos nos distintos níveis de ensino.

$\mathrm{Na}$ educação superior, por exemplo, com o fechamento das instituições, entrou "em cena" a modalidade do Ensino Remoto Emergencial (ERE) como uma forma de dar continuidade à profissionalização e formação dos estudantes universitários da graduação e pós-graduação. As aulas passaram a fazer uso de plataformas digitais como Ambientes Virtuais de Aprendizagem (AVA), por meio de encontros síncronos e complementos assíncronos com disponibilização de materiais digitais, desenvolvimento de atividades e aplicação de metodologias ativas com o auxílio das tecnologias digitais.

Os docentes universitários, no que lhes tocou, tiveram que dispor de uma energia singular para adaptarem-se à nova realidade educacional e (re)orientar suas práticas pedagógicas. De certo modo, colocaram-se em uma posição horizontal com o alunado, uma vez que estavam, na mesma proporção, constituindo-se como profissionais neste contexto emergente. Logo, diante desse momento de crise, podemos dizer que este trouxe um avanço para o cenário educacional: a centralidade no protagonismo discente, uma vez que, mediante o ERE, exige-se dos estudantes uma alta capacidade de autogestão da sua própria aprendizagem, o que remete ao professor uma condição de mediador e orientador deste trabalho pedagógico. Essa discussão não é nova na área educacional, entretanto, nos parece ter ganhado uma maior evidência durante esse período da pandemia da COVID-19. 
Partindo-se de tais pressupostos, a presente obra intitulada "Educação superior: experiências e (re)significações em tempos de pandemia da COVID-19" emerge como um esforço coletivo para a socialização de estudos e experiências desenvolvidas ao longo deste período pandêmico. Remete à reflexão acerca dos desafios, possibilidades e perspectivas para os diferentes agentes educacionais de modo a qualificar os processos de ensino-aprendizagem.

Neste sentido, esta coletânea reúne três textos organizados de modo sistemático e que visa a levar o leitor a aventurar-se nesses meandros que estão presentes na educação superior ao longo do momento que estamos vivendo. Ademais, torna-se uma obra histórica, uma vez que se constitui como uma produção coletiva por pesquisadores que exerceram a atividade docente ao longo da pandemia.

Sendo assim, o primeiro capítulo intitulado "Ressignificar e construir conhecimento: experiências de interação na educação superior" de Janaina Oliveira Silva, apresenta alguns apontamentos acerca da confluência estabelecida entre três aspectos da Educação a Distância: os agentes figurados como professor ou tutor, o estudante e o suporte para interação inserido no ambiente virtual de aprendizagem - AVA. O foco foi examinar aspectos singulares do processo de aprendizagem a distância a fim de que sejam desenvolvidas ações e estratégias para implementação de melhorias no circuito ensino-aprendizagem na modalidade de ensino que se utiliza de tecnologias da informação e comunicação (TIC).

O segundo capítulo, denominado "Metodologia do Ensino Superior numa versão remota: desafios e aprendizagens" de Arandi Róbson Martins Câmara, Elisângela Ribeiro de Oliveira Cabral e Regina Lúcia Alves Costa, trata dos resultados das leituras realizadas na disciplina de Metodologia do Ensino Superior no período de 10 de março a 29 de setembro de 2020. A oferta da disciplina iniciou de forma presencial e, em seguida, virtual/online.

Neste sentido, este capítulo visou referenciar as práticas docentes realizadas durante a disciplina Metodologia do Ensino Superior a partir das inferências apresentadas 
pelos discentes em depoimentos quando perguntados sobre as situações de aprendizagens durante o estudo no ensino remoto. Para análise do estudo, a metodologia utilizada envolveu as observações nas aulas online síncronas (em tempo real), tendo como base para a coleta de informações, as anotações individuais dos discentes e uma pesquisa, por meio da aplicação de um questionário, com uma representação da turma.

Por fim, o terceiro capítulo desta coletânea, nomeado "Eu, Você e Nós na educação superior: uma estratégia didático-pedagógica para potencializar o ensino-aprendizagem de métodos de integração no Cálculo Diferencial e Integral durante a pandemia da COVID-19" de Júlio Paulo Cabral dos Reis e Guilherme Mendes Tomaz dos Santos, apresenta uma estratégica utilizada em uma turma de graduação na disciplina em tela por meio da utilização da ferramenta online Edpuzzle. O texto apresenta a organização das sequências didáticas desenvolvidas com o grupo e, por meio de um relato de experiência, buscou evidenciar a percepção dos estudantes sobre a aprendizagem das integrais por meio das tecnologias digitais. Possibilita a reflexão e instrumentalização de docentes universitários para a adoção da ferramenta para o ensino de Cálculo, mas também, para outros campos do conhecimento.

Nesta perspectiva, entendemos que a presente obra poderá contribuir para a educação superior em diferentes aspectos, ou seja, na reflexão sobre o papel dos agentes educacionais, nas experiências vividas na graduação e pós-graduação, bem como a aproximação com ferramentas digitais que possam contribuir para práticas pedagógicas em diferentes contextos. Acreditamos que você, leitor, sairá com inquietações e motivado a (re)pensar sobre as nuances vivenciadas neste nível educativo ao longo da pandemia e para o retorno presencial. Entendemos, ainda, que a obra poderá trazer contribuições para uma (re)significação da educação superior em um cenário (pós)pandemia, de forma que possamos refletir sobre a (nova) normalidade educativa.

Por fim, desejamos a você, caro leitor, uma viagem de reflexões, aproximações e vislumbres sobre esse campo vasto, complexo, plural e diverso que é a educação superior. Certamente, você não sairá o mesmo sujeito após a leitura desta coletânea, uma 
vez que ela foi pensada para que pudéssemos perceber múltiplas possibilidades em um contexto adverso.

Sendo assim, agradecemos o seu interesse em ler a nossa obra e seja bem-vindo ao livro "Educação superior: experiências e (re)significações em tempos de pandemia da COVID-19”. Que ela possa contribuir, de alguma forma, para a sua vivência na área educacional e para a produção acadêmico-científica na educação superior. Desta forma, seja recebido de forma "calorosa" mesmo em um cenário de distanciamento social. Que a presencialidade seja percebida por meio dos discursos e estudos aqui reunidos.

\section{Os Organizadores}

Prof. Dr. Guilherme Mendes Tomaz dos Santos (UFRN - PNPD/CAPES) Prof. Me. Júlio Paulo Cabral dos Reis (IFMG - Campus Ibirité) 


\title{
SUMÁRIO
}

\author{
CAPÍTULO 1
}

RESSIGNIFICAR E CONSTRUIR CONHECIMENTO: EXPERIÊNCIAS DE INTERAÇÃO NA EDUCAÇÃO SUPERIOR 10

Janaina Oliveira Silva

doi: 10.48209/978-65-995948-3-1

\section{CAPÍTULO 2}

METODOLOGIA DO ENSINO SUPERIOR NUMA VERSÃO REMOTA: DESAFIOS E APRENDIZAGENS.

Arandi Róbson Martins Câmara

Elisângela Ribeiro de Oliveira Cabral

Regina Lúcia Alves Costa

doi: 10.48209/978-65-995948-3-2

\section{CAPÍTULO 3}

EU, VOCÊ E NÓS NA EDUCAÇÃO SUPERIOR: UMA ESTRATÉGIA DIDÁTICO-PEDAGÓGICA PARA POTENCIALIZAR O ENSINO-APRENDIZAGEM DE MÉTODOS DE INTEGRAÇÃO NO CÁlCULO DIFERENCIAL E INTEGRAL DURANTE A PANDEMIA DA COVID-19

Júlio Paulo Cabral dos Reis

Guilherme Mendes Tomaz dos Santos

doi: 10.48209/978-65-995948-3-3

SOBRE OS ORGANIZADORES. 


\title{
GAPÍTULO 1
}

\section{RESSICNIFICAR E CONSTRUIR} CONHECIMENTO:

\section{EXPERIËNCIAS DE INTERAÇĀONA EDUCACĀOSUPERIOR}

\author{
Janaina Oliveira Silva ${ }^{1}$
}

1 Graduada em Letras-Português pela Universidade de São Paulo (2004), Mestre (2008) e Doutora (2013) pelo Programa de Filologia e Língua Portuguesa da Universidade de São Paulo - Faculdade de Filosofia, Letras e Ciências Humanas. 


\section{INTRODUÇÃo}

As sociedades se modificam com o passar dos tempos, tais mudanças são favorecidas por diversos fatores (incluindo motivos históricos, econômicos, dentre outros), transformando os grupos sociais de acordo com as suas necessidades e a de seus sujeitos. Essas mudanças englobam setores diversos da economia, das tecnologias, da saúde, da gestão pública além dos setores da educação.

Dizer que a educação recebe influências sociais significa que de tempos em tempos ela precisa entender sua sociedade para absorver as necessidades que, e a partir delas, solicitar ao seu público um redimensionamento orientador partícipe no e para os processos inerentes ao ensino e à aprendizagem.

Nesse sentido,

A educação formal está num impasse diante de tantas mudanças na sociedade: como evoluir para tornar-se relevante e conseguir que todos aprendam de forma competente a conhecer, a construir seus projetos de vida e a conviver com os demais. Os processos de organizar o currículo, as metodologias, os tempos e os espaços precisam ser revistos. (MORAN, 2015, p. 15).

Ao considerarmos tais pressupostos, apresentamos alguns aspectos que participam do processo de ensino-aprendizagem no âmbito da $\mathrm{EaD}$, observando mais pontualmente ferramentas que consolidam e efetivam a interatividade/interação nessa modalidade de ensino. Assim, consideramos como objetivo central analisar a ferramenta de estratégia didático-pedagógica denominada por "fórum", compreendida por nós como um recurso de orientação didática-pedagógica para a transposição e aprofundamento de conteúdos em conhecimento acadêmico por meio da interatividade/interação (as)síncrona.

Para tal, como base para compor nosso corpus, analisamos o "fórum' disponibilizado no AVA de uma instituição brasileira de ensino, cujo portfólio de cursos de ensino superior incluem as áreas de exatas, humanas e de tecnologia, distribuídos entre bacharelados, licenciaturas e cursos superiores de tecnologia. Ressalte-se que todos os cursos da instituição têm previstas disciplinas na modalidade à distância, seja parcialmente, seja na sua integralidade. 
Nosso aporte teórico recai em estudos desenvolvidos por estudiosos do campo da educação, em particular, voltados à modalidade $\mathrm{EaD}$ de ensino, nomes como Moran (2015), Kenski (2008), Behar (2007), Lévy (1999; 2010), dentre outros, contribuem em nossas reflexões sobre a temática.

\section{SOBRE A EDUCAÇÃo À DISTÂNCIA NO CONTEXTO BRASILEIRO}

Os avanços tecnológicos, bem como os processos de globalização mundial, acentuaram a necessidade de otimização do tempo e do encurtamento das distâncias, além da crescente solicitação de sujeitos mais escolarizados pelo mercado de trabalho, são alguns dos fatores que contribuíram e oportunizaram uma crescente procura por cursos superiores na modalidade à distância.

Os índices apresentados no Censo do Ensino Superior de 2017 (CES), ao indicar o número de alunos matriculados na $\mathrm{EaD}$ entre os anos de 2009 e 2017, corroboram com essa visão:

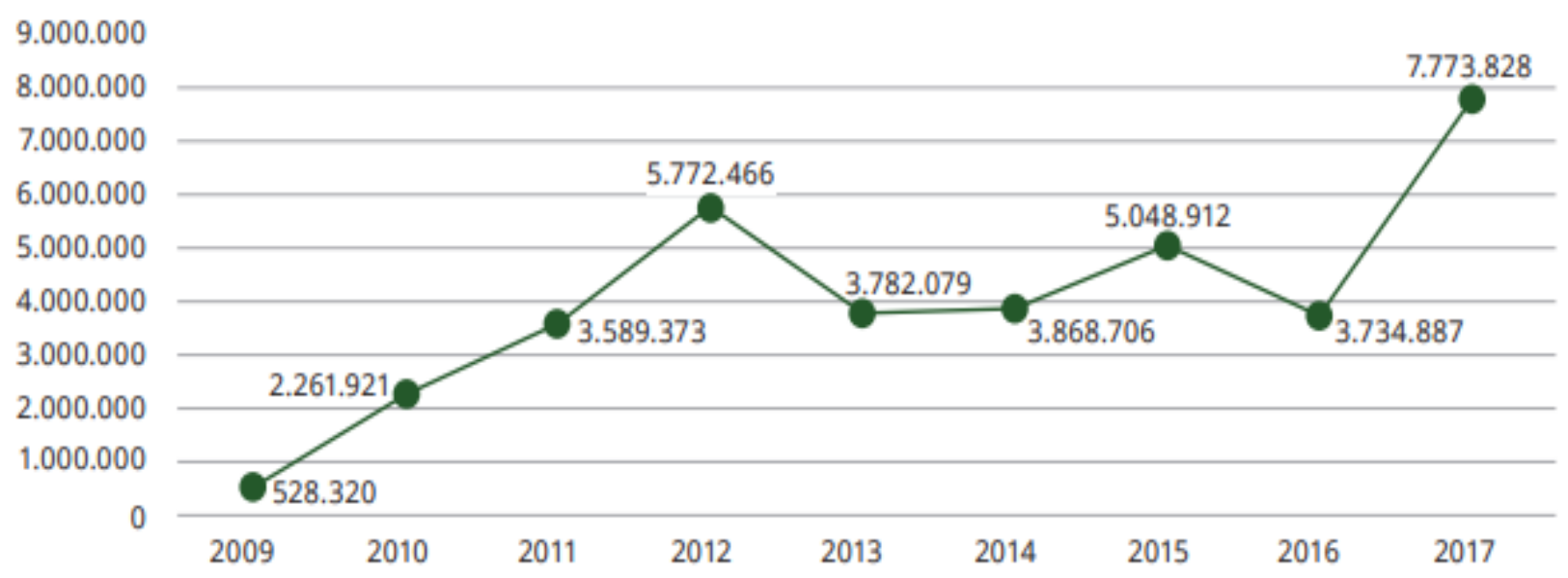

Disponível em: http://abed.org.br/arquivos/CENSO_EAD_BR_2018_digital_completo.pdf Acesso em: 13/04/2021. p. 67.

O crescimento apontado no gráfico acaba por incidir, consequentemente, no aumento do oferecimento de cursos superiores na modalidade à distância, por parte das instituições, como aponta o gráfico a seguir do Censo do Ensino Superior de 2017 (CES): 


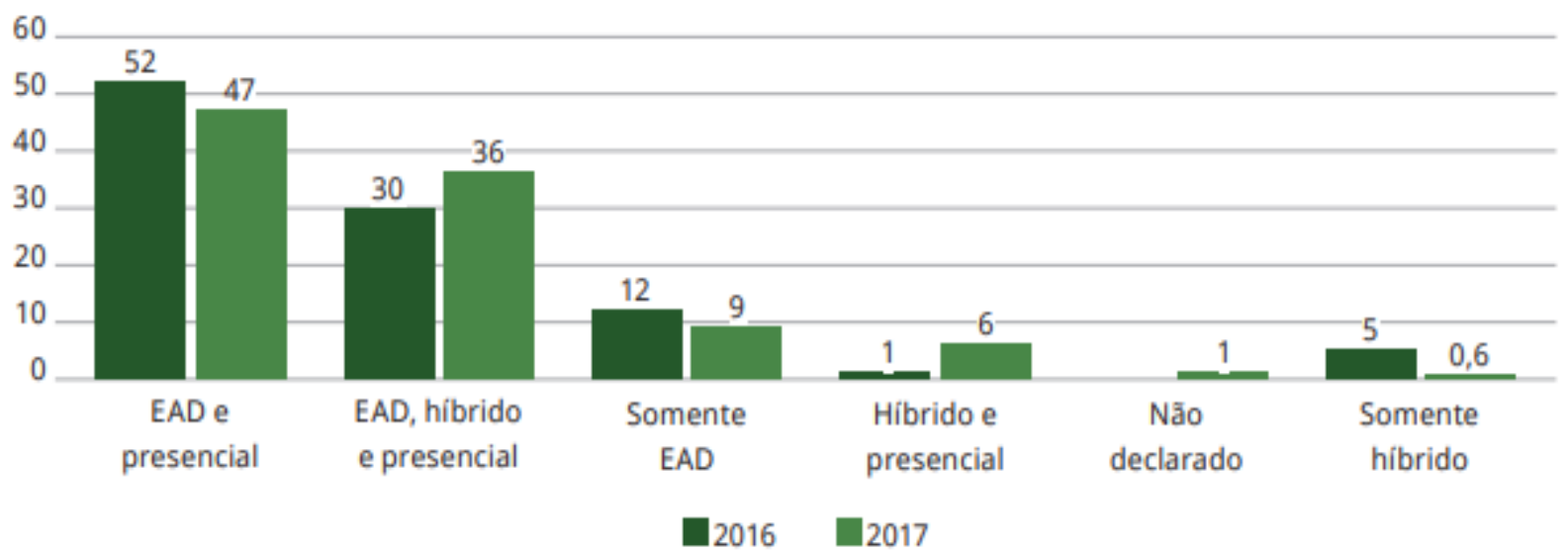

Disponível em: http://abed.org.br/arquivos/CENSO_EAD_BR_2018_digital_completo.pdf Acesso em: 13/04/2021. p. 52.

Ao ser considerado o contexto nacional, temos números que corroboram com o aumento dos cursos oferecidos na $\mathrm{EaD}$, sejam eles cursados "totalmente a distância", sejam eles no formato "semipresencial", como indicado no gráfico a seguir no referido CES de 2017:

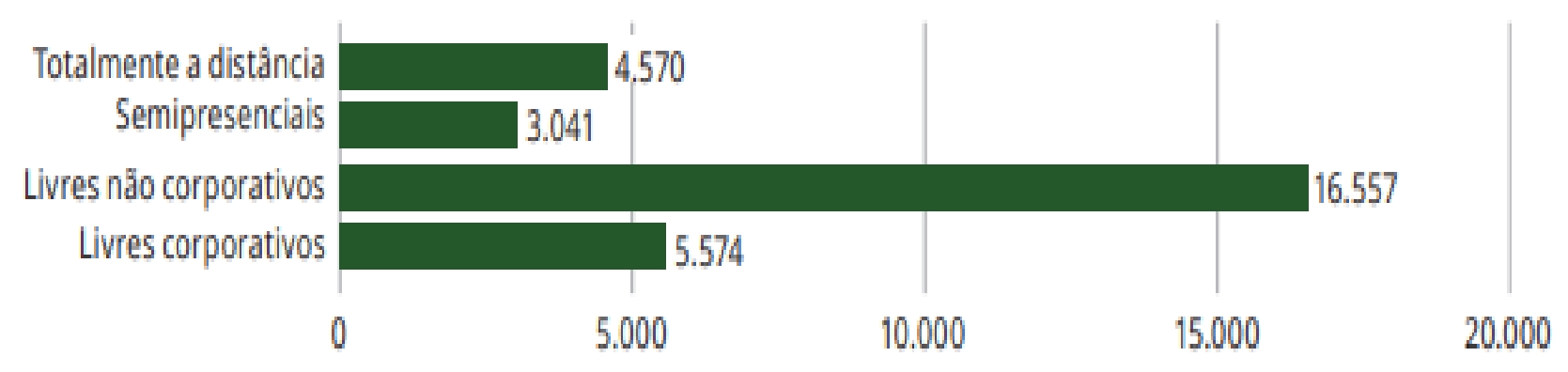

Disponível em: http://abed.org.br/arquivos/CENSO_EAD_BR_2018_digital_completo.pdf Acesso em: 13/04/2021. p. 63.

Tais números nos fazem pensar na representatividade e participação que a Educação à Distância (EAD) tem como fator singular da nossa contemporaneidade. Nas palavras de Kenski (2007) "Em um momento caracterizado por mudanças velozes, as pessoas procuram na educação escolar a garantia de formação que lhes possibilite o domínio de conhecimentos e melhor qualidade de vida". (KENSKI, 2007, p. 19).

Isso significa dizer que os grandes progressos nas tecnologias e mídias de informação e comunicação permitiram o desenvolvimento social que tomasse esses elementos 
como parte inerente ao seu tempo e aos seus espaços. Nesse sentido:

O que a tecnologia traz hoje é integração de todos os espaços e tempos. O ensinar e aprender acontece numa interligação simbiótica, profunda, constante entre o que chamamos mundo físico e mundo digital. Não são dois mundos ou espaços, mas um espaço estendido, uma sala de aula ampliada, que se mescla, hibridiza constantemente. Por isso a educação formal é cada vez mais blended, misturada, híbrida, porque não acontece só no espaço físico da sala de aula, mas nos múltiplos espaços do cotidiano, que incluem os digitais. O professor precisa seguir comunicando-se face a face com os alunos, mas também digitalmente, com as tecnologias móveis, equilibrando a interação com todos e com cada um. Essa mescla, entre sala de aula e ambientes virtuais é fundamental para abrir a escola para o mundo e para trazer o mundo para dentro da escola. (MORAN, 2015, p. 16).

Visto por esse viés, faz-se evidente que a nossa sociedade tem diante de si desafios que vão para além da sala de aula propriamente dita, ou melhor, a sala de aula convoca os atores educacionais a olharem por perspectivas novas ou, no mínimo, mais ligadas às necessidades da comunidade. A modalidade à distância não foge à regra, pois por exatamente não ter o convívio diário, típico da educação presencial, a EaD busca suprir essa falta por meio de estratégias e ferramentas pedagógicas que viabilizem a interação, com vistas, principalmente, a dar vazão à potencialidade do processo de ensino-aprendizagem.

\section{FERRAMENTAS PEDAGÓGICAS NA EAD}

No contexto da Educação a Distância espaço e tempo são elementos que não precisam coexistir simultaneamente, visto que a aprendizagem se constrói em tempos e lugares distintos, mais próximos aos sujeitos que participam do conjunto pedagógico inerente ao processo de ensino-aprendizagem. Isso significa que, se de um lado propõe-se a flexibilidade na construção do conhecimento; de outro, cria-se a sensação de distanciamento social.

O avanço nas tecnologias com a globalização da internet, permitindo a facilitação de acesso à grande parte da sociedade, faz com que os métodos tradicionais de ensino percam um pouco do seu sentido, visto que à distância de um clique, à frente de um com- 
putador, o sujeito tem a possibilidade de conseguir a informação que precisar, inclusive aquelas relacionadas ao âmbito do conhecimento acadêmico.

Nas palavras de Moran (2015):

O que a tecnologia traz hoje é integração de todos os espaços e tempos. O ensinar e aprender acontece numa interligação simbiótica, profunda, constante entre o que chamamos mundo físico e mundo digital. Não são dois mundos ou espaços, mas um espaço estendido, uma sala de aula ampliada, que se mescla, hibridiza constantemente. Por isso a educação formal é cada vez mais blended, misturada, híbrida, porque não acontece só no espaço físico da sala de aula, mas nos múltiplos espaços do cotidiano, que incluem os digitais. O professor precisa seguir comunicando-se face a face com os alunos, mas também digitalmente, com as tecnologias móveis, equilibrando a interação com todos e com cada um. (MORAN, 2015, p. 16).

Em consonância com o que nos aponta Moran (2015), os processos educacionais, sejam eles voltados à educação básica ou ao ensino superior, juntamente com o avanço tecnológico e com as mudanças na esfera social, ressalta a necessidade de hibridização, de mescla entre o "mundo físico e o mundo digital" (MORAN, 2015, p. 16).

Na Educação à Distância a interação se faz presente, contudo, utiliza-se mais dos recursos tecnológicos da informação e da comunicação. Muitos autores, como Silva (2012), destacam em seus trabalhos a apropriação e inclusão de ferramentas como o chat, jogos online, fórum, videoconferência, Wikis, podcast, animações, dentre outros, como recursos fecundos para um bom desenvolvimento do processo de ensino-aprendizagem, o que principalmente no caso da EaD, esse processo se consolida com o uso das tecnologias.

Nesse sentido, podemos afirmar que desenvolver procedimentos e estratégias que assegurem um aprendizado mais profundo sobre os temas investigados a fim de que haja melhora nas habilidades dos estudantes no registro documental, na análise das informações e na reflexão sobre a construção do conhecimento é, portanto, um desafio evidenciado na modalidade EaD. Nesse sentido, são desenvolvidos ferramentas e recursos dentro dos ambientes virtuais de aprendizagem os quais propiciam interatividade, tanto de maneira síncrona quanto assíncrona. 


\section{PROCEDIMENTOS E MÉTODOS}

Observar o lugar das ferramentas pedagógicas empregadas em cada curso habilitado na Educação à Distância e suas implicações no processo de ensino-aprendizado é elemento importante para assegurar eficácia e sucesso desse contexto educacional, pois é a partir delas que a $\mathrm{EaD}$ efetiva-se como modalidade válida.

Neste trabalho propomos observar o espaço de conversação destinado ao "fórum", seja ele de discussão, de informação, de aviso, ou de temáticas a fim de notarmos como as intervenções e interações entre professores tutores e alunos propiciam o desenvolvimento do protagonismo estudantil.

A escolha por acompanhar e analisar os fóruns de discussão do Ambiente Virtual de Aprendizagem (AVA) se dá por que a participação dos alunos nos fóruns é o momento em que se estimula a reflexão sobre o próprio aprendizado.

Para tanto, primeiramente, selecionamos a disciplina da qual extrairíamos nosso objeto de estudo. A escolha se deus por uma disciplina que perpassa vários dos cursos da instituição de ensino superior. Após a escolha pela disciplina, optamos por escolher um fórum que se mostrasse produtivo nas interações. $\mathrm{O}$ assunto mote do fórum circunscreve-se em tipos de abordagens metodológicas, que foi um assunto trabalhado em uma das aulas do curso. Esse fórum produziu mais de vinte interações entre alunos e professor tutor a partir de uma provocação pedagógica inicial por parte do condutor da conversação para o encaminhamento do aprendizado considerando as pautas estudadas em aula.

Os dados são informados de maneira anônima, a fim de manter em sigilo os sujeitos envolvidos.

\section{RESULTADOS E DISCUSSÃo}

Coletados os dados, podemos iniciar nossa discussão retomando o que Valente (2003) afirma sobre a interatividade no âmbito do processo de ensino aprendizagem: "A interação via internet tem como objetivo a realização de espirais de aprendizagem, facilitando o processo de construção de conhecimento" (VALENTE, 2003). 
Tendo em mente tal perspectiva, apresentamos os dados:

\section{Chamada do professor para a temática do fórum}

[...]

O conteúdo da semana trata sobre a produção de conhecimento e o aborda como "um método que foi planejado, organizado e que permita as pessoas entenderem como este conhecimento foi produzido". [...]

O fórum temático desta semana será sobre a pesquisa quantitativa versus a pesquisa qualitativa.

$[\ldots]$

Notemos que a chamada para a discussão temática se dá de modo bastante simples, em que o professor tutor faz um breve resumo do conteúdo e faz a indicação do foco que terá o fórum. Apesar de bastante discreta, a chamada para discussão surte em interação, dado que ao analisarmos o fórum notamos haver mais de vinte interações entre alunos e professor para o assunto abordado. A seguir, apresentamos dois desses momentos de interação no fórum.

\section{Interações - Alunos}

\section{Interação 1}

Interação 2

Elas têm diferenças entre si, mas resultam em uma conclusão de estudos e pesquisas, sejam elas baseadas em quantidades ou números (quantitativa) ou baseadas em fatos científicos através do raciocínio lógico (qualitativa).
A diferença entre as duas são respectivamente: a primeira realiza pequenas amostragens extraindo dados subjetivos com perguntas abertas que permitem conhecer melhor os indivíduos pesquisados; a segunda pesquisa permite analisar grande número de dados coletados de maneira fechada. 
Com os excertos apresentados notamos que a interação se fundamenta, por parte dos alunos, em criar um breve resumo do que eles entendem ser cada uma das abordagens tratadas na aula, com palavras próprias, certamente, apoiando-se no material disponibilizado em aula. Na interação 1 percebemos que o aluno focou em apontar as diferenças por oposição de ideias: "baseadas em quantidades ou números (quantitativa)" versus "baseadas em fatos científicos através do raciocínio lógico (qualitativa)", ou seja, o aluno apresenta uma definição sucinta do conteúdo da aula. Na interação 2 notamos que o aluno também apresenta uma definição, a partir de suas próprias palavras, sobre a temática abordada na aula, favorecendo o protagonismo estudantil no processo de ensino-aprendizagem.

Nas palavras de Lévy (1999):

Devemos construir novos modelos do espaço dos conhecimentos. No lugar de representação em escalas lineares e paralelas, em pirâmides estruturadas em 'níveis', organizadas pela noção de pré-requisitos e convergindo para saberes 'superiores', a partir de agora devemos preferir a imagem em espaços de conhecimentos emergentes, abertos, contínuos, em fluxo, não lineares, se reorganizando de acordo com os objetivos ou os contextos, nos quais cada um ocupa posição singular e evolutiva (LÉVY, 1999, p. 158).

Outro elemento a ser pensado acerca do objeto, no caso o fórum, refere-se à percepção de que a interação se dá de maneira assíncrona, ou seja, em tempos e espaços distintos de alunos e professor tutor. Contudo, a assincronicidade não é fator negativo, ao contrário, ao mesmo tempo em que se posiciona desse modo, permite ao aluno que haja tempo de maturação e reflexão sobre o assunto desenvolvido em aula. Isto é: o aluno considera a provocação pedagógica, ainda que assentada discretamente, e a responde à sua maneira, no seu tempo e no seu espaço de estudo.

Visto por este viés, o emprego da ferramenta "fórum" no processo de ensino-aprendizagem no âmbito da EaD corrobora com o que Behar (2008) afirma acerca dos modelos pedagógicos que são mediados por tecnologias da comunicação e informação, isto é, a interatividade como ferramenta pedagógica propicia o desenvolvimento da construção do conhecimento de forma significativa. 
Com isso, temos que os resultados esperados baseiam-se na premissa de que um processo educativo deve contemplar um aprendizado pautado em ações e intervenções visando o desenvolvimento de competências que permitam lidar com a construção do conhecimento em ambiente virtual, em particular, nas salas de fóruns (temáticas, de discussão ou outras), assim, ao empregarmos ações e estratégias pedagógicas teremos resultados que levam a uma aprendizagem reflexiva e protagonizada pelo estudante, com vistas a uma formação profissional mais completa e adequada à sociedade contemporânea.

\section{CONSIDERAÇÕES FINAIS}

Ao pensarmos o processo de ensino-aprendizagem no âmbito da Educação à Distância somos levados a considerar aspectos como a interação, o tempo e o espaço. Esses três elementos, no contexto da sala de aula virtual, designado como Ambiente Virtual de Aprendizagem - AVA, participam no desenvolvimento do protagonismo estudantil.

Com a finalidade de refletirmos sobre a problemática, escolhemos pensar a interação a partir da ferramenta "fórum". Para tal, assentamos nossa discussão em trabalhos desenvolvidos por estudiosos como Moran (2015), Kenski (2008), Behar (2007), Lévy (1999; 2010), dentre outros.

Assim, a análise dos dados nos permite afirmar que o uso de tecnologias no âmbito da Educação à Distância $(\mathrm{EaD})$ facilita a promoção da interatividade aliadas às ferramentas pedagógicas desenhadas com essa finalidade. $\mathrm{O}$ fórum propicia a interação entre dois dos agentes do processo de ensino-aprendizagem: professor tutor e aluno, promovendo uma aprendizagem mais humanizada e significativa.

\section{REFERÊNCIAS}

BEHAR, P. A. et al. Modelos pedagógicos em educação a distância. Porto Alegre: Artmed, 2008.

BRASIL. Lei $\mathrm{n}^{\circ}$ 9.394, de 20 de dezembro de 1996. Estabelece as diretrizes e bases da educação nacional. Diário Oficial da União, Brasília, 23 de dezembro de 1996. Disponível em: <http://www.planalto.gov.br/ccivil_03/leis/L9394.htm>. Acesso em: 13 out. 2020 . 
BRASIL. Ministério da Educação; Secretaria de Educação Básica; Secretaria de Educação Continuada, Alfabetização, Diversidade e Inclusão; Secretaria de Educação Profissional e Tecnológica. Conselho Nacional de Educação; Câmara de Educação Básica. Diretrizes Curriculares Nacionais da Educação Básica. Brasília: MEC; SEB; DICEI, 2013. Disponível em: $<$ http://portal.mec.gov.br/index.php?option=com_docman\&view=downloa$\mathrm{d} \&$ alias $=13448$-diretrizes-curiculares-nacionais-2013-pdf\&Itemid=30192> . Acesso em: 13 out. 2020.

CASTADELLI, G. A. Currículo e tecnologia digital. In: Castadelli, G. A. Currículos e desafios contemporâneos. São Paulo: SAGAH, s/d.

KENSKI, Vani Moreira. Educação e Tecnologias: O novo ritmo da informação. Campinas: Papirus, 2007.

LÉVY, P. Cibercultura. São Paulo: Editora 34, 1999.

. A inteligência coletiva: por uma antropologia do ciberespaço. São Paulo: Loyola, 2010.

MOORE, Michael; KEARSLEY, Greg. Educação a Distância: uma visão integrada. São Paulo: Thomson Learning, 2007.

MORAN, J. Mudando a educação com metodologias ativas. In: Convergências Midiáticas, educação e cidadania: aproximações jovens, 2015. Disponível em: http://www2.eca. usp.br/moran/wp-ontent/uploads/2013/12/mudando_moran.pdf

PIMENTEL, Mariano; FUKS, Hugo (organizadores). Sistemas Colaborativos. Rio de Janeiro: Elsevier, 2011.

SILVA, M. A formação de professores para a docência online. São Paulo: Ed. Loyola, 2012.

VALENTE, J.A. A espiral da aprendizagem e as tecnologias da informação e comunicação: repensando conceitos. In: JOLY, M.C. (Ed.) Tecnologia no ensino: implicações para a aprendizagem. São Paulo: Casa do Psicólogo, 2002. p.15-37.

VALENTE, J.A. Educação a distância no ensino superior: soluções e flexibilizações. Revista Interface - Comunicação, Saúde, Educação. Vol.7 no.12. Botucatu. 2003. Disponível em: https://www.scielo.br/scielo.php?script=sci_arttext\&pid=S1414-32832003000100010 


\title{
GAPÍTULO 2
}

\section{METODOLOCIADOENSINO}

\section{SUPERIOR NUMA VERSĀOREMOTA:}

\section{DESAFIOSE APRENDIZACENS'}

\author{
Arandi Róbson Martins Câmara ${ }^{2}$ \\ Elisângela Ribeiro de Oliveira Cabral ${ }^{3}$ \\ Regina Lúcia Alves Costa ${ }^{4}$
}

1 Atividade realizada como requisito avaliativo para a conclusão da Disciplina Metodologia do Ensino Superior, ministrada pelos professores doutores: Betânia Leite Ramalho e Guilherme Mendes Tomaz dos Santos.

2 Doutorando em educação no PPGED/UFRN. Professor do Instituto de Educação Superior Presidente Kennedy. ORCID: E-mail: arandi@ifesp.edu.br.

3 Mestranda no Programa de Pós-graduação em Educação pela Universidade de Brasília (UnB), Brasília - DF - Brasil. (UnB/FE/PPGE). Professora do Instituto de Educação Superior Presidente Kennedy ORCID: https://orcid.org/0000-0002-7904-7041.. E-mail: elisangela@ifesp.edu.br

4 Mestranda em educação no PPGED/UFRN. Professora do Instituto de Educação Superior Presidente Kennedy. ORCID: https://orcid.org/0000-0001-5665-0094.Email: regina@ifesp.edu.br. 


\section{INTRODUÇÃo}

A humanidade enfrenta pandemias desde os tempos mais remotos. Pandemia é um termo usado para descrever uma situação em que uma doença infecciosa ameaça milhões de pessoas ao redor do mundo, simultaneamente. O planeta Terra vive, nesse momento, uma pandemia, decretada pela Organização Mundial de Saúde - OMS, em 11 de março de 2020, causada pelo novo coronavírus. A COVID-19 é uma doença infecciosa causada pelo novo coronavírus, identificado pela primeira vez em dezembro de 2019, em Wuhan, na China. As evidências disponíveis atualmente apontam que o vírus causador da COVID-19 pode se espalhar por meio do contato direto, indireto (através de superfícies ou objetos contaminados) ou próximo (na faixa de um metro) com pessoas infectadas através de secreções como saliva e secreções respiratórias ou de suas gotículas respiratórias, que são expelidas quando uma pessoa tosse, espirra, fala ou canta.

As pessoas que estão em contato próximo (a menos de 1 metro) com uma pessoa infectada podem pegar a COVID-19 quando essas gotículas infecciosas entrarem na sua boca, nariz ou olhos. Nesse contexto, sem a existência de vacinas, a recomendação é fazer uso de máscaras e ter atitudes de distanciamentos para a proteção de si e dos outros.

Para conter a propagação do vírus são utilizadas algumas estratégias, dentre elas, medidas de distanciamento social que consistem em exigir que todos os setores da sociedade permaneçam nas suas residências durante a vigência da decretação da medida pelos gestores locais. Esta medida restringe ao máximo o contato entre pessoas.

Neste sentido, as Instituições de ensino começam a pensar estratégias para a continuidade das atividades acadêmicas, considerando essa nova realidade, a impossibilidade das aulas presenciais. Diante dessa situação, surge a necessidade emergencial para enfrentar o cenário de distanciamento social.

A tomada de decisão rápida para adequar um modelo de ensino que oportunizassem a retomada das aulas não presenciais foi formalizada nas instituições de ensino e dentre as possibilidades, instituiu-se o ensino remoto no Brasil, por meio da Portaria $\mathrm{n}^{\circ}$ 343 de 17 de março de 2020 (atualmente revogada pela Portaria ${ }^{\circ} 544$ de 16 de junho 
de 2020), esta substitui as aulas presenciais por aulas em meios digitais enquanto durar a situação de pandemia do Novo Coronavírus - COVID-19 (BRASIL, 2020).

Para o Ensino Superior, a Lei 10.040/2020, orientou conforme Art. $3^{\circ}$ o desenvolvimento de atividades pedagógicas não presenciais, por meio do uso de tecnologias da informação e comunicação, para fins de integralização da respectiva carga horária exigida.

Neste sentido, instituições realizaram pesquisas junto ao corpo discente para avaliar a possibilidade de acesso às aulas via Internet e conforme resultado, foi retomada às atividades acadêmicas, com a oferta de algumas disciplinas, garantindo aos alunos com dificuldades para acesso virtual, o direito de cursar as disciplinas ofertadas remotamente, numa etapa seguinte, de forma presencial.

Vale ressaltar que, muitas instituições retomaram suas atividades e foram adequando-as conforme suas realidades, sempre considerando o contexto social e econômico dos seus alunos.

Das experiências observadas, nesse retorno, algumas optaram por elaborar e imprimir atividades ou mesmo gravaram aulas, disponibilizaram em canais de TV abertos, ambas situações comuns nas escolas da Educação Básica, para contemplar alunos com dificuldades de acompanhar as aulas por meio de plataformas digitais.

Outras organizaram suas atividades a partir de plataformas que possibilitavam aulas online (em tempo real) explorando aplicativos que permitiam a realização de vídeos chamadas, nesse caso, a experiência que vivenciamos na disciplina Metodologia do Ensino Superior.

Diante disso, o estudo visa referenciar práticas docentes realizadas na disciplina Metodologia do Ensino Superior, ofertada de forma remota, via Google Meet, tendo como base nas inferências apresentadas pelos discentes em depoimentos quando perguntados sobre as situações de aprendizagens durante o estudo.

A relevância desse estudo justifica-se pela viabilidade observada durante as aulas remotas na referida disciplina, quando novas práticas de ensinar e aprender foram in- 
corporadas, tornando os momentos mais enriquecedores, mesmo em ambiente virtual, a participação ativa não foi comprometida nesse processo.

Para a realização do estudo, a metodologia utilizada envolve a pesquisa-ação, pois há a participação direta dos pesquisadores. Quanto à abordagem qualiquantitativa, as informações coletadas favoreceram a associação de dados qualitativos e quantitativos e permitiu ampliar o olhar sobre pontos complexos do objeto da investigação. Os instrumentos e procedimentos utilizados foram: questionário semiestruturado, apresentando questões fechadas e abertas; observação direta a partir das anotações individuais dos pesquisadores, durante as aulas. Na observação procurou-se identificar e esclarecer fenômenos que envolveram práticas pedagógicas vivenciadas nas aulas que contribuíram para o processo de ensino-aprendizagem.

Para compreender as práticas docentes vivenciadas na disciplina, autores como RAMALHO e NUÑEZ (2003); GAUTHIER (2003) foram selecionados para legitimar as inferências apresentadas quanto às necessidades formativas dos professores em desenvolvimento permanente. Quanto a base que fundamenta o estudo sobre o olhar para metodologias utilizadas MORAN e BACICH, MASETTO e BEHRENS (2013), PRAT e PALOFF (2015) referenciam às práticas identificadas nos professores titulares da disciplina.

Como resultado, observou-se a estudo a relevância, principalmente quanto aos saberesdocentes necessários para o desenvolvimento de metodologias que atendam as diferentesformas de ensinar e consequentemente de aprender, seja em espaços físicos presenciais ou virtuais.

O projeto de escrita do artigo está organizado na seguinte ordem: I introdução - nesta seção é apresentada o contexto da pesquisa, objetivo, justificativa, metodologia utilizada, base teórica e resultados; II Base Epistemológica e Metodológica que visa fundamentar as inferências observadas no estudo; III Análise dos Resultados e IV Considerações. 


\section{DA PRESENCIALIDADE À VIRTUALIDADE: DESAFIOS DA ATIVIDADE DOCENTE}

Os desafios observados no cenário atual, com mudanças bruscas nas práticas sociais, impulsionam novos saberes à atividade docente. Isso exige do professor novas aprendizagens que lhes permitam tomar decisões para enfrentar situações adversas, principalmente advindas das novas tecnologias digitais que transformam diariamente a comunicação entre as pessoas, bem como a forma de produzir e acessar as informações.

Esse enfoque nos permite refletir sobre quais conhecimentos, saberes e práticas precisamos incorporar às atividades profissionais dos professores para ensinar, diante de um cenário de permanente mudanças, seja no contexto atual, pelo distanciamento social ou mesmo pela evolução da sociedade. Os desafios são permanentes, pois como afirma RAMALHO e NUÑEZ (2014, p.50) “ensinar não é uma tarefa fácil, banal, intuitiva e descolada de uma base de conhecimento profissional".

Portanto, entender que aprendizagens são necessárias ao desenvolvimento do professor, observamos, no cenário de distanciamento social, este profissional reinventando suas práticas, mesmo reconhecendo que esses professores possuem crenças, ideias e concepções, conhecimentos, atitudes sobre o ensino (NUÑEZ e RAMALHO, 2014), ainda assim, se desafiaram para atender à situação emergencial.

Nessa mesma perspectiva, a necessidade formativa, Nóvoa (2020) concebe que o professor deve sair do campo da denunciação para o campo da enunciação, aquele que busca solução, o professor pesquisador.

Dessa forma, compreende-se como um componente essencial a aprendizagem, o conhecimento e a educação como um bem comum mundial baseada nos princípios da dimensão coletiva, como tarefa social, que corrobora para a responsabilidade compartilhada e o compromisso com a solidariedade (UNESCO, 2016).

Em tempos de tensões, é imprescindível promover a educação em direitos humanos, considerando que os seres humanos compartilham valores, virtudes e sentido de justiça. 
A escola não se constitui apenas para aluno aprender, ela é espaço também para professores aprenderem continuamente a partir das análises, dos projetos em que estão envolvidos tanto no que diz respeito a observação e a instrução. A autonomia profissional e a colaboração com os colegas requer aprendizado contínuo e um ambiente ótimo. Para tanto, faz-se necessário uma mudança cultural, considerando o professor como aprendiz não apenas como fonte de conhecimento num processo de participação contínua e colaborativa, responsiva.

Todos esses fatores dependem da clareza de como organizar atividades para que esses objetivos sejam contemplados. Necessitamos de uma engenharia pedagógica, teoria e objetivo de aprendizagem.

\section{O contexto das aulas remotas na disciplina de Metodologia do Ensino Superior}

O avanço das tecnologias digitais possibilita inúmeras formas de acesso à informação e comunicação e tem nas últimas décadas encurtado distâncias geográficas em todo o mundo. Recentemente, observamos a intensificação das interações sociais mediadas pelas tecnologias, com o distanciamento social, consequência da Pandemia da COVID-19.

O bom uso das tecnologias contribui para diminuição das desigualdades, porém a intensidade das tecnologias pode trazer danos, o que exige estratégias e avanços do ensino. É importante o equilíbrio do uso das tecnologias e da didática.

A tecnologia cria possibilidade de boa instrução para todos, diminuindo as desigualdades. As dificuldades são nas rotinas pedagógicas e deve-se considerar a estrutura dos objetivos de aprendizagem que são: o que ensinar, como ensinar e como avaliar.

Rapidamente, os aparelhos tecnológicos tornaram-se imprescindíveis para as pessoas, seja em diferentes situações de comunicação e contextos, como no trabalho, no entretenimento e lazer e na educação.

Nas relações de trabalho, ao adotar como estratégia, o trabalho Home Office (trabalho em casa), empresas implantaram e/ou implementaram as tecnologias digitais, 
ex-plorando plataformas para continuidade das atividades e, as redes sociais foram se consolidando como uma forma rápida e eficiente de divulgação, compra e venda de produtos. Esse fato impulsionou mudanças e com isso empresários foram convencidos que era necessário repensar seus negócios.

No lazer e entretenimento não foi diferente, principalmente, com o fluxo intenso de conexões estabelecidas pelas redes sociais na Internet. Através de links pode-se perceber as diversas maneiras de interações sociais entre pessoas, no âmbito do ciberespaço, sendo essas síncronas e assíncronas, diferenciando-as pela temporalidade de participação.

Na Educação com a suspensão das atividades presenciais, as tecnologias digitais da informação e comunicação - TDIC, ganhou espaço e foi incorporada em muitas instituições de ensino. Essa mudança rápida se constituiu como um grande desafio para professores e estudantes, pois a inserção de práticas pedagógicas mediadas por tecnologias ainda se apresentava de forma tímida nas instituições, pois até,

Algum tempo atrás, a polêmica se instaurava sobre o uso ou não de tecnologias no processo educacional em virtude da identificação da tecnologia com o uso apenas operacional e comportamentalista das estratégias desvinculadas das preocupações com o desenvolvimento das pessoas. (MASETTO, 2013, p.141).

No cenário atual, com a perspectiva da oferta do Ensino Remoto mediado por tecnologias, ampliou as possibilidades para a retomada das atividades acadêmicas e novamente, o fenômeno das redes sociais permitiram a circulação de práticas pedagógicas integradas as tecnologias, criando novos agrupamentos sociais interconectados, como: palestras, vídeo aulas, seminários, aulas ao vivo, entre outras práticas. Todas organizadas e compartilhadas em plataformas por professores para que os estudantes interajam e participem.

Ao integrar as tecnologias em suas práticas pedagógicas, o professor assumiu uma nova atitude, pela diversidade de ferramentas, viu-se diante do desafio de adaptar-se a elas para dar sentido ao uso e favorecer o processo de ensino-aprendizagem.

Da vasta disponibilidade de ferramentas tecnológicas disponíveis, neste estudo destacamos as experiências com as plataformas SIGAA, Google Meet e o aplicativo 
WhatsApp. Além dessas ferramentas, a plataforma do Youtube também foi utilizada para o compartilhamento das aulas gravadas.

É importante destacar que a experiência foi desafiadora para a maioria dos envolvidos, professores titulares da disciplina, discentes e professores convidados. Contudo, aprender juntos constituiu-se como uma prática permanente durante toda a disciplina. Essa afirmação se evidencia nos materiais utilizados para análise sobre as experiências adquiridas na disciplina. (Questionário, aplicativo WhatsApp e anotações individuais dos pesquisadores).

Percebemos assim, que a metodologia utilizada nas aulas favoreceu interações diferenciadas, verbal (áudio) ou escrita (chat). As participações dos alunos se intensificaram conforme necessidades e interesses sobre o tema da aula.

Nesse sentido, foi possível observarmos a intensa interação pelo volume de contribuições, registrados no chat. Em algumas aulas foram registradas mais de 100 participações, isso indica que a participação ativa na disciplina, constitui-se como uma estratégia didática "para alcançar bons resultados no ambiente online, os alunos precisam ser ativos, criativos e envolvidos com o processo de aprendizagem" (PALOFF e PRATT, 2015. p.126).

Portanto, pensar como os ambientes online foram explorados, na disciplina, pode ser uma oportunidade para a apropriação metodológica do uso das tecnologias, como meio de personalização e aproximação das aprendizagens desejadas dos alunos. Ficou claro durante o estudo e pesquisa como as ferramentas tecnológicas escolhidas pelos professores proporcionaram gradativamente a interatividade de alunos e professores.

Então, como pensar em boas práticas de ensino mediadas pelas tecnologias digitais, num contexto que constatamos uma infinidade de ferramentas e aplicativos disponíveis? Que conhecimentos e habilidades serão necessárias para que o professor possa escolher a tecnologia mais adequada à realidade dos alunos, de maneira sábia?

Cabe refletir sobre a formação continuada dos professores para auxiliá-los no desenvolvimento de habilidades que lhes permitam mudar suas práticas, integrando-as novos processos e novas relações mediadas por tecnologias digitais. 
Ambientes acolhedores influenciam na construção de boas experiências, assim a pesquisa aplicada com uma representação da turma procurou revelar como estudantes da disciplina de Metodologia no Ensino Superior avaliam aulas remotas.

\section{O QUE REVELAM OS DADOS CONSTRUÍDOS COM BASE NA PESQUISA}

Para analisar as experiências do ensino na disciplina, os dados construídos a partir do questionário e anotações individuais dos pesquisadores, permitiram observar aspectos importantes que consolidam o impacto positivo das metodologias utilizadas para ensinar, no formato remoto, mesmo essa experiência sendo nova para todos.

A proposta era identificar boas práticas que permitam os estudantes se envolverem com a sua aprendizagem. Por isso, elaboramos um questionário com perguntas abertas e questões de múltiplas escolhas, para compreender como os estudantes avaliaram as metodologias, recursos utilizados, temas abordados, participação e interação na disciplina.

Os dados da pesquisa são resultados do questionário enviado para uma representação de estudantes do mestrado, doutorado e alunos especiais que participaram da disciplina. Não foram estabelecidos critérios para a seleção dos estudantes, aleatoriamente enviamos o questionário pelo aplicativo WhatsApp, individualmente.

As perguntas que tratam essa pesquisa diz respeito ao perfil acadêmico do estudante, expectativas da disciplina para o ensino remoto, acesso e compartilhamento do material via SIGAA, o uso do Google Meet para momentos síncronos (em tempo real), comunicação interativa no grupo do WhatsApp, metodologias utilizadas, viabilidade das estratégias, para estudo e participação, relevância dos temas e autores.

Os gráficos a seguir representam a leitura que realizamos a partir do questionário aplicado. Para dialogar com a análise das informações construídas, reportamos as anotações individuais e gravações das aulas. A ideia é integrar nesta análise as percepções dos pesquisadores: o dito na oralidade (gravações), o registrado (anotações individuais) e as respostas do questionário (formulário online). 
Assim, iniciamos a análise identificando os estudantes da pesquisa e seu vínculo acadêmico. O gráfico 1 representa o lugar de fala de cada estudante.

\section{Gráfico 1 - Perfil Acadêmico}

\section{VÍNCULO ACADÊMICO COM A DISCIPLINA}

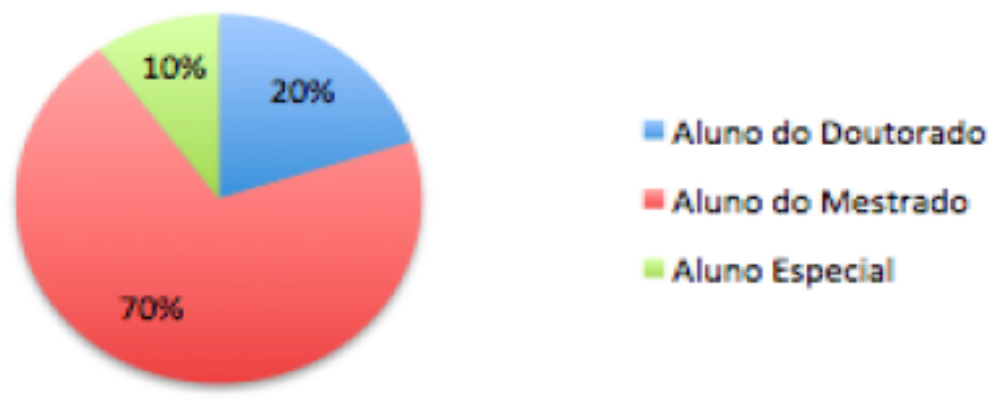

Fonte: Autores. 2020

Dos dados coletados, observamos que os estudantes regulares do mestrado, doutorado e alunos especiais, prontamente responderam o questionário encaminhado, isto revela o interesse e o comprometimento em contribuir com o nosso estudo, pois imediatamente, coletamos os dados solicitados.

Outro fator observado, foi o resultado da participação, a maioria das respostas correspondem à estudantes do mestrado $70 \%, 20 \%$ estudantes do doutorado e $10 \%$ alunos especiais.

Podemos assim, fazer inferência a elevada proporção de pessoas que entende o papel da formação continuada como necessária à sua aprendizagem e ao desenvolvimento profissional. Nessa perspectiva, a formação continuada é entendida como processo de apropriação sistemática e formal da cultura profissional que contribui para a identidade profissional (RAMALHO e NUNEZ, 2014).

Então para compreender como as práticas docentes impactam diretamente no envolvimento e participação dos estudantes, as respostas apresentadas no Gráfico 2 eviden- 
cia que se a Disciplina Metodologia do Ensino Superior ofertada no formato remoto com aulas síncronas, interações no aplicativo WhatsApp ${ }^{1}$ ee compartilhamento de materiais para estudo via $\mathrm{SIGAA}^{2}$, atendeu suas expectativas quanto à participação e interação entre os professores titulares e colegas estudantes. Os respondentes da pesquisa consideram a implementação dos recursos tecnológicos de apoio às atividades como viável nesta experiência.

\section{Gráfico 2 - Metodologia e recursos utilizados nas aulas remotas}

\section{Metodologias e recursos: expectativas atendidas}

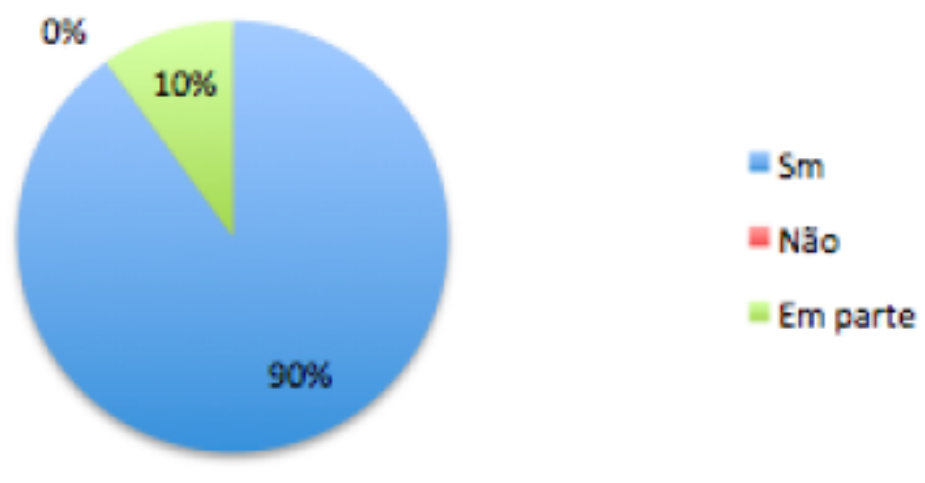

Fonte: Autores. 2020

Nos dados observados, constatamos que $90 \%$ dos participantes afirmaram que a disciplina de metodologia do ensino superior atendeu às expectativas, mesmo sendo ofertada no formato remoto. Apenas $10 \%$ dos participantes avaliaram que a disciplina atendeu em parte. Importante ressaltar que não tivemos nenhum estudante que desaprovou a oferta da disciplina, no formato remoto, na sua totalidade.

1 Aplicativo usado para troca de mensagens via conexão com a Internet. Atualmente é o aplicativo mais usado no mundo, pois permite chamadas de voz, vídeo, compartilhamentos de arquivos, sejam estes: imagens, textos, áudios, entre outros. Destaca-se da comunicação via chat (disponíveis em algumas plataformas) por manter a mensagem ativa, mesmo quando estamos off-line. Saiba mais sobre o aplicativo acessando: https://www.whatsapp.com/

2 Sistema Integrado de Atividades Acadêmicas, disponibilizado em ambiente virtual de aprendizagem em que professores e estudantes podem interagir, virtualmente, por fóruns, enquetes, mensagens, entre outros, pela Web. https://sigaa.ufrn.br/sigaa 
Diante dessas evidências, podemos inferir que a oferta da disciplina, de forma remota, não comprometeu a participação e frequência nas aulas. E mais, provocou nos professores e estudantes um novo olhar para o uso das tecnologias digitais, rompendo barreiras, aprendendo novas formas de comunicação, reinventando a sala de aula presencial.

A propósito, como podemos refletir um cenário educacional pós-pandemia? A dinâmica da sala de aula presencial será a mesma?

Existem maneiras diferentes de ensinar e de se apropriar do conhecimento (BACICH e MORAN, 2015), nessa perspectiva não podemos mais observar o cenário educacional, limitando-o apenas ao espaço físico da sala de aula, organizada em instituições de ensino.

Hoje, com a perspectiva do ensino híbrido, os espaços de ensino-aprendizagem são rotativos e dinâmicos, podem ser alternados, enriquecidos em ambientes virtuais, permitindo a personalização individual, pois embora o objetivo seja comum, os caminhos são diferentes ou mesmo se ajustam às experiências dos alunos. Mesmo tendo clareza das possibilidades de interações por meio das tecnologias, essas não dão conta de lidar com toda a riqueza de uma relação

Os gráficos 3 e 4 indicam a visão dos estudantes acerca das estratégias utilizadas para o compartilhamento do material de leitura, estudo e comunicação via SIGAA e o aplicativo WhatsApp. 


\section{Gráfico 3 - Recurso SIGAA}

\section{Compartilhamento de materiais via SIGAA}

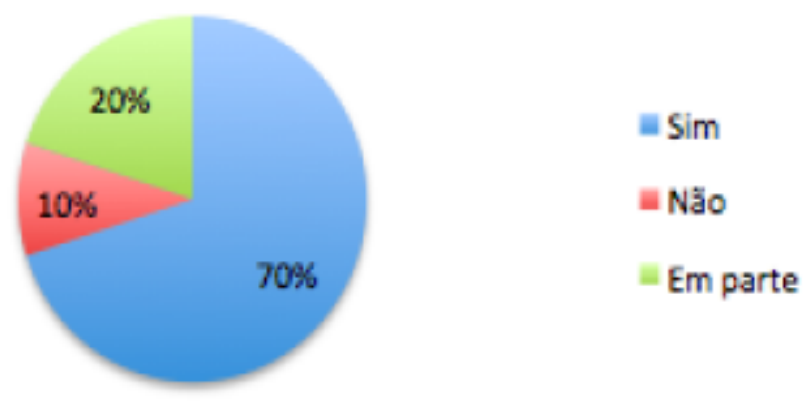

Fonte: Autores, 2020

\section{Gráfico 4 - Recurso WhatsApp}

\section{Interação diária via WhatsApp}

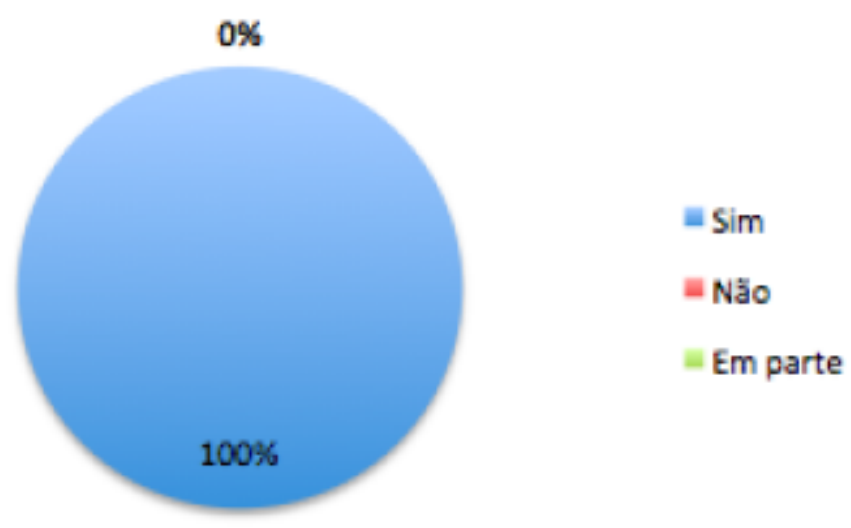

Fonte: Autores, 2020

Ao perguntar sobre o aplicativo para interação e a plataforma para compartilhamento e envio de atividades, procurou-se saber o quanto os recursos tecnológicos escolhidos facilitam o acesso ao material e o aplicativo para viabilizar a comunicação instantânea. De acordo com os dados coletados, $70 \%$ dos estudantes responderam SIM, validando a estratégia escolhida pelas habilidades apresentadas no sistema. 20\% responderam EM PARTE, consideram o sistema SIGAA como um recurso administrativo, $10 \%$ dos estudantes afirmaram NÃO, visto que sempre depende de alguém para ajudar. 
Como podemos perceber, pouco mais de dois terços dos entrevistados aprovam plenamente o uso do SIGAA. Diante disso, podemos entender que essa parcela de estudantes já faziam uso do sistema, mesmo antes da pandemia.

A questão 5 abordava sobre o uso do aplicativo WhatsApp, se o grupo do WhatsApp facilitou a comunicação instantânea, entre professores e estudantes, pela rapidez com que as informações e as respostas eram disponibilizadas.

Com base nos dados, 90\% responderam que SIM, que as informações eram esclarecedoras e rápidas e apenas $10 \%$ dos estudantes disseram que havia excesso de informações.

Diante dessa constatação, acreditamos que o êxito do uso do aplicativo na disciplina de Metodologia do Ensino Superior deu-se devido o WhatsApp fazer parte da rotina das pessoas e adequação dessa comunicação ao formato remoto. Será que a partir de agora todas as turmas terão seu grupo de WhatsApp independente de pandemia?

A estratégia de aproximação e comunicação via WhatsApp, se constitui em uma realidade comum na organização de grupos, conforme interesses (pessoais ou profissionais) e finalidades, a comunicação e o compartilhamento de informações ganham rapidez e objetividade. As pessoas informam e são informados sobre os acontecimentos, muitas vezes em tempo real, isso gera a dependência de manter-se conectados 24 horas.

Assim como uma rede social, o aplicativo WhatsApp incorpora recursos diversos, imagens, textos, vídeos, áudios que podem ser acessados, muitas vezes de forma off-line.

\section{Gráfico 4 - Aulas online via Meet}

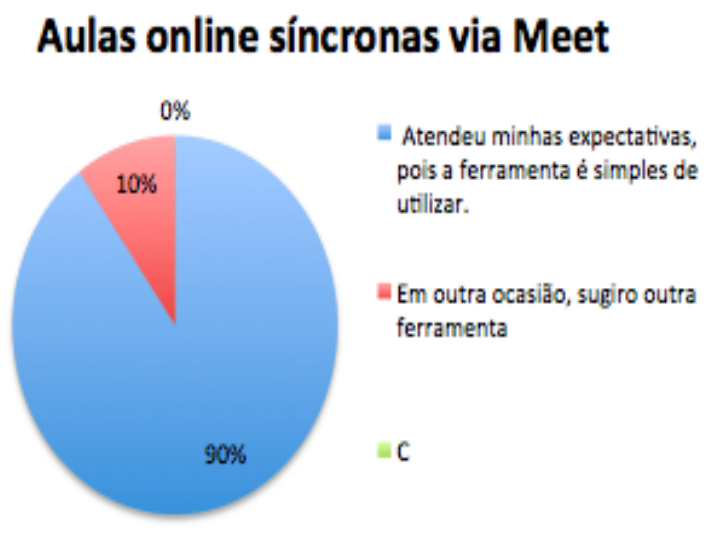

Fonte: Autores, 2020 


\section{Imagem 1 - Metodologia utilizada nas aulas}

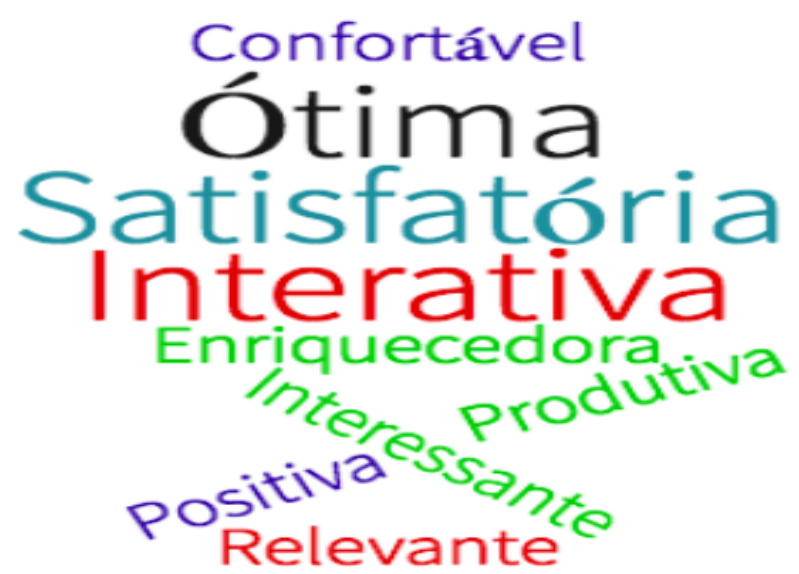

Fonte: Autores, 2020

O gráfico 4 trata do uso da ferramenta Google Meet para a interação online (síncrona) tendo como perspectiva a aproximação do universo presencial para o virtual, por meio de vídeo chamada ao vivo. A referida ferramenta permite a exibição dos participantes, além de está disponível para computadores e aparelhos móveis. No entanto, vale ressaltar que outras ferramentas estão disponíveis para uso digital, nesse mesmo formato, como: Plataforma ZOOM, Webex Meetings, Microsoft Teams, entre outras, porém o Google Meet tem na versão gratuita o acesso amplo de participantes (em torno de 250), o que facilita organizar com mais segurança às atividades acadêmicas, mesmo para turmas numerosas. Outro fator determinante é a facilidade de acesso e utilização, como foi afirmado pelos participantes da pesquisa.

Os dados apresentados confirmam a escolha dos professores pelo Google meet, pois $90 \%$ dos estudantes responderam que a ferramenta atendeu às expectativas, devido a simplicidade de uso. Apenas $10 \%$ dos estudantes sugeriram o uso de outra ferramenta em uma outra ocasião e nenhum participante da pesquisa considerou a ferramenta meet muito limitada.

Quanto às metodologias utilizadas pelos professores titulares da disciplina, discentes convidados e pelo professor palestrante na aula de encerramento, a imagem 1 revela o grau de satisfação dos estudantes. 
No tocante a metodologia utilizada durante as aulas, as respostas dos participantes apontam o grau de satisfação bastante expressivo. A questão 6 foi elaborada de forma aberta e na análise dos textos produzidos, centramos em registrar, as palavras-chave (Imagem 1), os conceitos que estavam presentes nos textos. As palavras Ótima, Satisfatória e Interativa foram as mais evidenciadas. As referidas palavras podem fazer surgir na memória de longo prazo uma série de conceitos que estão a elas associados (GAUTHIER, 2014), assim, ótima pode representar a total aceitação e aprovação da situação de aprendizagem para os estudantes.

Ainda sobre os textos produzidos nas respostas dos participantes, a expressão que complementa a avaliação da metodologia, ganhou visibilidade por abordar como relevante para a formação como professor pesquisador, é de fato, o reconhecimento à adequação da metodologia para o ensino remoto.

Para outros estudantes, identificar a metodologia da sala de aula como produtiva, interessante, positiva e enriquecedora (grifo nosso), consolidam as percepções das palavras-chave.

Outro ponto relevante é perceber que não há respostas sem nenhum ponto que identificasse inadequação nas escolhas metodológicas ou mesmo insatisfação por parte dos estudantes participantes da disciplina.

Portanto, a metodologia utilizada favoreceu, aos participantes da pesquisa, boas experiências para aprendizagens durante as aulas.

Isso também se evidenciava quando o tempo definido para o término das aulas era sempre ampliado para além do horário estabelecido e a maioria $(90 \%$ permanecia atentos e participativos (conforme registradas nas gravações).

Para analisar se as estratégias didático-pedagógicas dos professores como: exposição oral na aula, apresentação de slides, diálogos via chat, facilitaram a compreensão dos temas e a participação na aula (via Meet). 
Gráfico 5 - Estratégias pedagógicas

\section{Estratégias para exposição dos temas na sala de aula online}

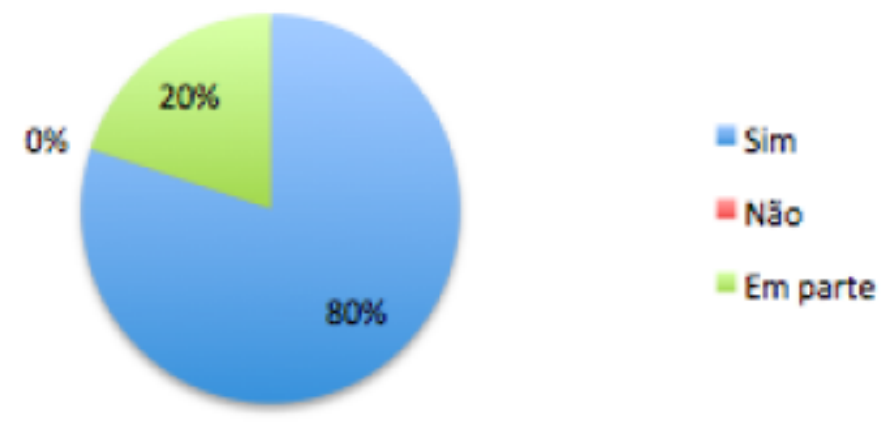

Fonte: Autores. 2020

\section{Gráfico 6 - Temas estudados na disciplina}

\section{Temas estudados na disciplina}

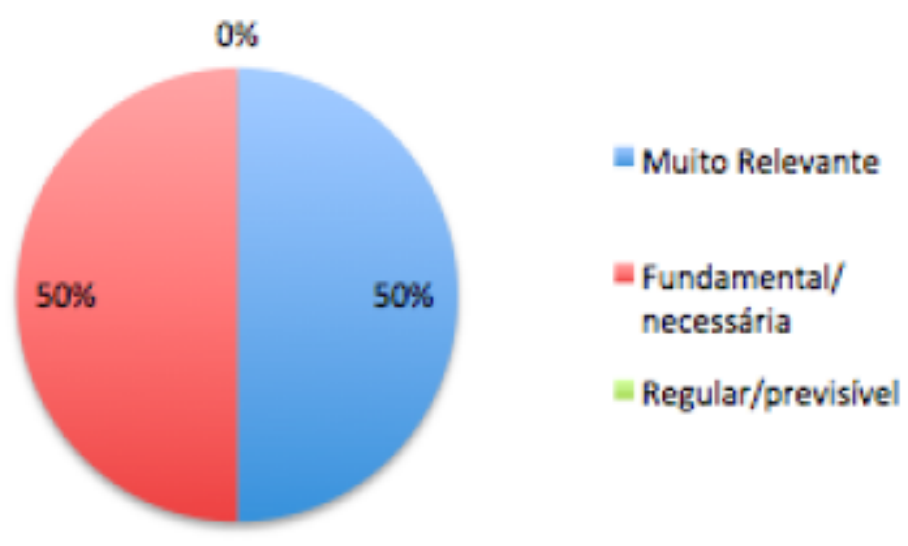

Fonte: Autores. 2020

Vale lembrar que tanto a exposição oral, quanto a apresentação dos slides são estratégias bem constantes também na aula presencial, no entanto, a participação dos estudantes ganha outro recurso além da oralidade, a comunicação escrita por meio do Chat. O chat caracteriza-se por ser um espaço, no qual o estudante pode interagir com os professores e os colegas, realizando saudação de chegada e despedida, fazendo perguntas, inserindo comentários, compartilhando material via link, entre outras utilidades. 
De acordo com os dados, $70 \%$ aprovaram as estratégias utilizadas pelos professores da disciplina e 30\% responderam que atendeu em parte as estratégias. Destacar que não houve nenhuma reprovação com relação às estratégias utilizadas durante a disciplina.

O gráfico 6 avaliou os temas e autores selecionados para serem estudados na disciplina. De acordo com os dados apresentados, $100 \%$ dos estudantes avaliaram fundamental e relevante a seleção do material discutido durante as aulas, sendo, $50 \%$ para cada categoria e nenhum estudante avaliou como regular essa questão.

Quando questionado sobre os temas estudados e o pleno atendimento, conforme a Ementa da Disciplina de Metodologia do Ensino Superior foi sugerido que os participantes da pesquisa, referenciasse dois temas que considerou essencial para sua formação enquanto pesquisador. A tabela 1 traz os temas apresentados no questionário.

\section{Tabela 1 - Temas ministrados durante as aulas e considerados essenciais pelos participantes para a sua formação}

\section{Respostas dos participantes}

A perspectiva histórico-cultural e a teoria do engajamento

Recursos digitais e profissionalização docente.

Ensino-aprendizagem de estudantes da educação básica; Ensino Explícito como uma metodologia eficiente de ensino.

Aprendizagem da docência, Profissionalização da docência

Aprendizagem e engajamento estudantil no ensino superior

Ensino-aprendizagem; uso das ferramentas tecnológicas

As tecnologias nas práticas docentes e a abordagem sobre ensino e desempenho do estudante segundo Gauthier

Formação docente, tecnologias e as orientações dos Organismos internacionais para uma agenda educacional

Rigor na pesquisa e ensino explícito.

Uso das tecnologias em sala de aula e a responsabilidade do estudante no seu processo educativo. 
Dos temas estudados durante a disciplina de Metodologia de Ensino Superior tiveram destaques as temáticas relacionadas ao processo de ensino-aprendizagem e o uso das tecnologias digitais como estratégia de ensino.

\section{CONCLUSÃO}

Sabemos dos desafios que a sociedade enfrenta, com o distanciamento social. As as atividades antes presenciais, foram substituídase adaptadas para um formato virtual, cujaa maioria da população tinha pouca experiência. Ansiedades e desejos de oportunizar a continuidade das atividades acadêmicas, nos fez mergulhar num cenário ainda pouco conhecido por uma grande parcela da sociedade. Entendemos ainda a importância da ciência do comportamento, estratégia social como a melhor forma de conter uma epidemia.

Aprender e ensinar por meio das tecnologias foi o principal desafio. Que práticas e recursos foram ao longo desse processo sendo implementadas efetivamente para garantir a participação de todos professores e estudantes? Instituições procuraram informações sobre os estudantes, alguns apresentavam anseios, curiosidades, outros limitações de diversas ordens.

Frente às mudanças, os estudantes da disciplina Metodologia do Ensino Superior, validam a experiência das aulas, quando aprovam os recursos tecnológicos utilizados, as abordagens metodológicas e as estratégias de participação e interação.

O formato online da disciplina, consolidou as práticas sociais presentes na sociedade atual. Hoje, as interações sociais são mediadas por tecnologias integradas a ambientes e redes, a comunicação vai se transformando e novas linguagens são incorporadas de forma instantânea.

Embora desafiador, é preciso refletir sobre essa experiência. Convivemos durante semanas pertos uns dos outros, apenas uma tela nos distanciava, no entanto, o toque, o do olho no olho a espontaneidade presente no espaço físico não pode ser mensurado, pois uma tela uma tela fria dura imparcial nos fazia perceber o silêncio, não apenas como ausência de som, mas evidenciava que estávamos distantes, isolados. Por isso, outros 
recursos foram implementados para aproximar a interação, com o grupo do WhatsApp a comunicação instantânea intensificou o diálogo entre professores e estudantes. Todos tinham sempre algo para compartilhar.

Portanto, o que nos revelou essa pesquisa a partir das respostas dos participantes? Pelo nível de aceitação dos estudantes, a metodologia utilizada pelos professores foi envolvente e integrativa, pois embora a turma fosse numerosa, todos estavam assiduamente em sala de aula. Outro fator marcante foi o tempo destinado às aulas, geralmente ampliado pela riqueza das informações e interações no chat. Em momentos as contribuições e debates excederam 100 mensagens, conforme anotações dos pesquisadores.

\section{REFERÊNCIAS}

BRASIL. Lei n. 10.040, de 18 de agosto de 2020. Estabelece normas educacionais excepcionais a serem adotadas durante o estado de calamidade pública, Brasília, DF, agosto de 2020. Disponível em: .http://www.planalto.gov.br/CCIVIL_03/Portaria/PRT/ Portaria\%20n\%C2\%BA\%20343-20-mec.htm. Acesso em: 16 de outubro de 2020.

GAUTHIER, Clermont. Ensino explícito e desempenho dos alunos: a gestão dos aprendizados. São Paulo. Vozes, 2014.

MORAN, José Manuel; MASETTO, Marcos T.; BEHRENS, Marilda Aparecida. (Ed.) Novas tecnologias e mediação pedagógica. 21 ed. Campinas, SP: Papirus, 2013. 171 p.

PALLOF, Rena M.; PRATT, Keith. (Ed.) Lições da aula virtual: as realidades do ensino online. 2 ed. Porto Alegre: Penso, 2015. 202 p.

RAMALHO, Betania Leite. NUÑEZ, Isauro Beltrán [Org.]. Formação, representações e saberes docentes: elementos para se pensar a profissionalização dos professores. 1 ed. Campinas, SP. Mercado das Letras, 2014.

UNESCO. Repensar a educação: rumo a um bem comum mundial. UNESCO Brasil. 2016. Disponível em https://unesdoc.unesco.org/ark:/48223/pf0000244670. Acesso em: 17 de setembro de 2020 


\title{
GAPÍTULO 3
}

EU, VOCÊE ENÓS NA EDUCAÇĀO SUPERIOR: UMA ESTRATÉCIA DIDÁTICO-PEDACÓCICA PARA POTENCIALIZAR O ENSINO-APRENDIZAGEMDEMÉTODOS DE INTECRACĀO NO CÁLCULO DIFERENCIAL EINTECRAL DURANTE A PANDEMIA DA COVID-19

\author{
Júlio Paulo Cabral dos Reis ${ }^{1}$ \\ Guilherme Mendes Tomaz dos Santos ${ }^{2}$
}

1 Mestre em Ensino de Ciências e Matemática pela Pontifícia Universidade Católica de Minas Gerais (PUC-Minas). Licenciado em Matemática pela mesma instituição. Coordenador Adjunto do Grupo de Estudos sobre Docência Universitária em Educação Matemática (GEDUEM) e Integrante do Grupo de Estudos sobre Internacionalização da Educação Básica e Superior (GEIEBES). Professor Efetivo do Instituto Federal de Educação, Ciência e Tecnologia de Minas Gerais (IFMG/Campus Ibirité).E-mail para contato: julio.reis@ifmg.edu.br

2 Pós-Doutorando no Programa de Pós-Graduação em Educação pela Universidade Federal do Rio Grande do Norte (PPGED/UFRN). Bolsista PNPD/CAPES. Doutor e Mestre em Educação pela Universidade La Salle (UNILASALLE) com período sanduíche (em ambas as formações) pela Universidade La Salle México (ULSA). Professor Substituto do Núcleo de Educação da Infância - Colégio de Aplicação da Universidade Federal do Rio Grande do Norte (NEI/CAp-UFRN). Professor Colaborador no Programa de Pós-Graduação em Inovação em Tecnologias Educacionais (PPgITE/ UFRN). Coordenador do Grupo de Estudos sobre Internacionalização da Educação Básica e Superior (GEIEBES) e Coordenador do Grupo de Estudos sobre Docência Universitária em Educação Matemática (GEDUEM). E-mail para contato: mendes.guilherme234@gmail.com 


\section{CONSIDERAÇÕES INICIAIS}

Já não é de hoje que as tecnologias digitais da comunicação e informação (TDIC) contribuem ao cenário educacional. Elas, como recursos educacionais, oferecem um conjunto quase que imensurável de possibilidades de utilização. Tais possibilidades depende do conhecimento - específico de área, de metodologias educacionais, de recursos tecnológicos - bem como, da criatividade, da afinidade e identificação do docente/usuário para elaborá-las, implantá-las (agregando, complementando outras já existentes, dentre outros), aplica-las, avalia-las e refletir todo o processo.

A tríade computador/smartphone/internet, talvez seja, a primordial ou a com maior representatividade das TDIC na atualidade. Voltados à área educacional, é possível a utilização de softwares livres (que oferecem: planilhas, plotagens, programação, edição, dentre outros), a visualização de vídeos/animações/simulações (documentários, videoaulas, vides explicação etc.), acesso a ambientes virtuais de aprendizagens (AVA), objetos de aprendizagens tecnológicos, entre outras possibilidades. Deste modo, esta tríade contribui demasiadamente aos processos de ensino-aprendizagem ${ }^{3}$.

Com o advento da pandemia da COVID-19, as TDIC tiveram maior destaque e evidência como recursos didático-pedagógicos, principalmente, no ambiente escolar e acadêmico. Ademais, tornou-se um fator decisivo de interação na relação professor-aluno, na construção de conhecimentos durante este período pandêmico. Seja de modo síncrono ou assíncrono, o acesso à tríade funciona (ou) quase como um fator determinístico na qualidade da implementada modalidade de ensino: o Ensino Remoto Emergencial (ERE). De acordo com Arruda (2020), o ERE emerge como uma modalidade que se assemelha à educação a distância, contudo, possui um caráter de excepcionalidade em virtude do período no qual se está vivenciando, ou seja, em um contexto pandêmico.

Neste cenário, a educação, básica e superior, recorrereu a diversas metodologias educacionais já conhecidas e outras que emergiriam pelas necessidades exigidas no momento. Frente a esse movimento, foi necessário a realização de adaptações, (re)elabo-

3 Sabemos que nem todo estudante tem acesso condizente/satisfatório aos recursos digitais e tecnológicos, porém, o objetivo/foco deste capítulo não é realizar tal discussão. Entendemos, que esta reflexão é relevante. Contudo, serve como decorrência da pesquisa. 
ração de estratégias, implementação de instrumentos que subsidiassem os processos de ensino-aprendizagem por meio da utilização das TDIC, de modo que se pudesse efetivar a relação pedagógica.

Assim, a aula presencial foi substituída pelo denominado encontro síncrono, principalmente de março de 2020 até o primeiro semestre de 2021. O trabalho com as temáticas, projetos, conhecimentos a serem desenvolvidos, dentre outros foram passados para o assíncrono. De modo que a carga horária fosse cumprida em detrimento aos dias letivos flexibilizados.

No assíncrono, muitas das vezes, o docente ficou a cargo de elaborar os instrumentos, implementar, avaliar e refletir sobre os trabalhos desenvolvidos. Mesmo no assíncrono, muitas instituições, utilizou da tríade para executá-lo. Além, de todos os desafios que se pode pensar neste cenário, destacamos aqui, o desafio de avaliar a construção de conhecimentos nesta modalidade de ensino.

Assim, os objetivos deste capítulo consiste em apresentar a estratégia denominada "Eu, Você e Nós" e relatar a primeira aplicação da mesma em curso de graduação de uma instituição federal Tal estratégia foi criada, com os objetivos de construir conhecimentos e avaliar tal construção de conhecimentos sobre a temática - métodos de integração de funções reais de uma variável. Tais métodos de integração foram: (a) substituição; (b) por partes; (c) integrais trigonométricas; (d) substituição trigonométrica e (e) por frações parciais, presentes na disciplina de Cálculo Diferencial e Integral do Curso de Engenharia de Controle e Automação de uma instituição federal.

A estratégia tem por base a resolução de exercícios ou problemas. Compreendendo por Pozo (2008, p. 253) que uma situação proposta como exercício pode ser compreendida e tornar-se um problema "na medida em que existe um reconhecimento dela com problema por parte do aluno e na medida em que este não dispõe de procedimentos de tipo automático que lhe permitam solucioná-la de forma mais ou menos imediata".

O recurso tecnológico "vídeo" foi utilizado na implementação da estratégia. Quatro vídeos foram criados, editados, implementados e compartilhados pelo docente da disciplina. Os quatro vídeos compunham o que o discente nomeou como "Teste Avaliativo 
2". Para compartilhar e avaliar a construção de conhecimentos dos discentes utilizou-se a ferramenta online gratuita chamada Edpuzzle ${ }^{4}$. Esta ferramenta traz a possiblidade da criação de vídeos interativos ${ }^{5}$, pela permissividade de edição/modificação de vídeos criados pelo próprio usuário ou disponíveis em redes como YouTube e Khan Academy. A interação ocorre por acréscimo de questões abertas ou fechadas, links, e/ou áudios complementares durante a execução do vídeo.

Em suma, a estratégia Eu, Você e Nós foi criada como um instrumento de avaliação da temática supracitada. Os resultados obtidos mostraram que os discentes se sentiram mais motivados e com a sensação de interação e amparo na construção de conhecimentos pela utilização das TIDC pela estratégia utilizada. Além disso, por relatos deles via análise de questões fechadas e abertas, foi possível notar a aprendizagem de conceitos relacionadas as temáticas trabalhadas ${ }^{6}$.

\section{APRESENTAÇÃo INICIAL DA ESTRATÉGIA EU, VOCÊ E NÓs}

A estratégia foi criada para ser aplicada em um instrumento pedagógico avaliativo na disciplina de Cálculo Diferencial e Integral, modalidade ERE. O referido instrumento recebeu o nome de teste avaliativo 2 , cuja a construção de conhecimentos sobre a temática - métodos de integração - foi avaliada pela aplicação dele. O teste avaliativo 2 trouxe quatro vídeos interativos para os discentes. Durante a execução dos vídeos, questões abertas e fechadas foram propostas.

Tais questões, ao findar do teste, foram avaliadas via plataforma. As fechadas, por implementação e, as abertas, pelo docente. Todas elas tinham uma escala de 0 a $100 \%$, de modo que, ao final do processo, a média das porcentagens foi calculada e convertida

4 Disponível em: https://edpuzzle.com/ . Um tutorial para os leitores interessados pode ser acessado em: https://youtu.be/YCEcU0KE3oE.

5 Compreendemos vídeos interativos como vídeos que ofereçam durante o processo de execução questões abertas e/ou fechadas sobre a temática em tela; permissão de complementos da temática por links; dentre outras ações;fazendo com que o espectador interaja pela resolução, escolha ou reflexão do que lhe é solicitado.

6 Como todo recurso pedagógico, a estratégia criada, trouxe desafios, potencialidades e dificuldades, tanto de implementação e utilização, o que ficará para uma próxima oportunidade de pesquisa. Neste capítulo o foco foi apresentar a estratégia criada, como foi estruturada, aplicada e os resultados obtidos. 
por regra de três simples na nota real dentro da disciplina (valor de 10,0 pontos dos 100,0 pontos a serem distribuídos no semestre).

O teste avaliativo 2 - métodos de integração - foi composto pelos vídeos interativos: [vídeo1] método da substituição e introdução ao método de integração por partes - exercícios e exercícios/problemas envolvendo área de regiões limitadas por curvas-gráfico de funções de uma variável real, distância e deslocamento (onde distância e deslocamento eram modelados por funções de uma variável real). O [vídeo2] apresentou a finalização do método de integração por partes e introdução ao a integrais trigonométricas - exercícios.

Já o [vídeo3] foi demonstrada a finalização do cálculo de integrais trigonométricas e introdução ao método de substituição trigonométrica - aplicações envolvendo trabalho realizado por uma força, impulso e dedução de uma fórmula para o cálculo de área de uma região limitada por uma elipse. Por fim, o [vídeo4] contemplou o término da dedução de uma fórmula para o cálculo de área de uma região limitada por uma elipse (utilizando o método de substituição trigonométrica) e integração por frações parciais - aplicação no cálculo de área de uma região (região limitada por curvas-gráfico de funções reais de uma variável).

Para realizar todo o teste avaliativo $2^{7}$, os quatro vídeos, cada um com o tempo máximo de vinte minutos, deveriam ser assistidos e realizadas as atividades propostas. Porém, para tal foi dado o período de trinta dias (um mês comercial) e os vídeos deveriam ser assistidos na ordem, contudo, não necessariamente no mesmo dia. Era solicitado ao início vídeo que o discente tivesse lápis, papel e suas anotações pessoais, pois durante a realização do teste iria precisar delas. Então, a estratégia - Eu, Você e Nós consiste em três passos. Neste momento, apresentaremos os três passos e, ao longo da leitura do texto, esmiuçaremos cada um deles.

[1] primeiro passo - o EU - o docente resolve um exercício para revisar e/ou construir conhecimentos sobre o método de integração pretendido.

7 Importante ressaltar ao leitor, que a proposta se configura como uma atividade avaliativa em que os métodos de integração já tinham sido trabalhados em encontros síncronos e de modo assíncrono outrora na disciplina. 
[2] segundo passo - o VOC $\hat{E}$ - o discente, então é convidado a resolver um exercício análogo utilizando o método trabalhado no primeiro passo.

[3] terceiro passo - o NÓS - em conjunto docente (gravação/edição) e discente/ presente/virtual resolviam uma situação-problema (aplicação), que recorria a métodos de integração trabalhados anteriormente na disciplina.

Começaremos, então, a descortinar a estratégia criada pelo seguinte caminho: [a] relataremos sobre a construção dos vídeos interativos; [b] aplicação do teste avaliativo 2 - presença da estratégia; [c] principais resultados - comentários dos discentes sobre a experiência ${ }^{8}$ e [d] dificuldades/desafios para o docente durante o processo.

\section{CONSTRUÇÃO DOS VÍDEOS INTERATIVOS}

A escolha pelo recurso vídeos foi embasada na leitura de Borba e Domingues (2015), que evidenciam a utilização de vídeos para a construção de conhecimentos matemáticos. Os autores os utilizaram de variadas plataformas e dos mais variados tipos (palestras, situações-problema construídos pelos discentes, dentre outros), evidenciando que vídeos podem ser um recurso pedagógico facilitador para a aprendizagem. De modo que “a Internet, em suas múltiplas dimensões - biblioteca virtual, meio de comunicação, locus de publicação - possibilita que vídeos sejam utilizados por docentes em sala de aula [...]. (BORBA; DOMINGUES, 2015, p.194, grifo nosso). Os autores relatam a utilização de vídeos em sala de aula desde o ano de 2009. Sendo assim, migrar da sala de aula presencial para modalidade ERE agregando este recurso pode trazer possibilidades positivas para potencializar os processos de ensino-aprendizagem e dos processos avaliativos.

O docente, conheceu a ferramenta online Edpuzzle em conversas entre os pares, ainda, quando se fazia o ensino presencial. Por curiosidade acadêmica, estudou sobre tal ferramenta em momentos distintos como forma para ampliar o seu repertório e qualificar o desenvolvimento profissional. Nela, há possibilidade de editar vídeos (seja do usuário

8 Ressaltamos que o capítulo tem por objetivo apresentar a estratégia. Neste viés, se configura como um relato de experiência. Isto é, analisar em que medida a estratégia criada potencializou os processos avaliativos e/ou de ensino-aprendizagem. 
e/ou de outras plataformas), gravar áudio por cima do áudio original (isto permite criar notas em áudio em pontos relevantes do vídeo ou complementando tais pontos), inserir textos, criar questões (abertas ou fechadas), feedbacks (seja por áudio, nas próprias questões, por textos e/ou no próprio vídeo). Lembrando que a combinação destes recursos origina novas possibilidades pedagógicas. Ademais, pode aguçar a criatividade do usuário/docente na construção, elaboração, implementação dentre outros recursos pela ferramenta em tela.

Um vídeo com tais possibilidades se configura, neste contexto, como um vídeo interativo. Pela inserção/implementação de tais estratégias e ao compartilhar com os discentes, é possível, configurar as interações na linha de tempo do vídeo, fazendo com que elas ocorram nos times previstos, de modo, a solicitar a interação do discente.

A construção dos quatro vídeos interativos do teste avaliativo 2, utilizando a estratégia: Eu, Você e Nós, seguiu a sequência: elaboração dos scripts (sequência didática) $\rightarrow$ implementação dos scripts (sequência didática) em slides $\rightarrow$ gravação por captura de tela da sequência didática $\rightarrow$ edição da gravação realizada $\rightarrow$ Upload do vídeo criado para o Edpuzzle $\rightarrow$ implementação das possibilidades mencionadas para um vídeo interativo.

Os scripts foram escritos trazendo: [a] o método de integração a ser trabalhado; [b] os exercícios que seriam trabalhados; [c] as situações-problema/exercícios que seriam trabalhadas; e [d] as questões abertas, fechadas, notas explicativas, dentre outras possibilidades que seriam inseridas e em que momentos seriam incorporadas.

Os slides foram elaborados com base nos scripts. Eles, por sua vez, permitem animações, visualizações agradáveis, representações pictóricas (gráficos de funções, representação de regiões, dentre outros). Na figura 1 temos um destes slides construídos. Vejamos: 
Figura 1: Exemplo de um slide utilizado9

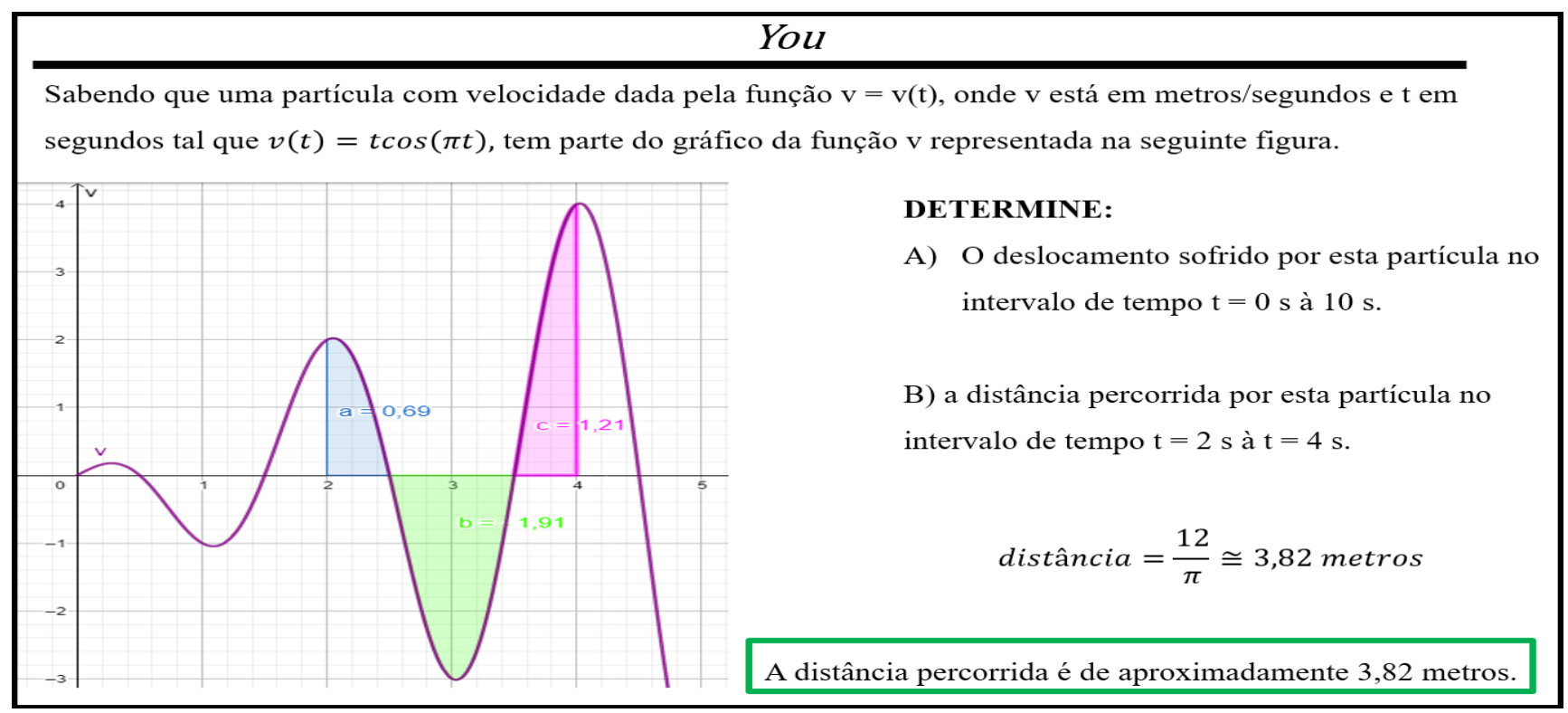

Fonte: Os autores (2021)

A gravação do vídeo, por captura de tela, foi realizada seguindo o script implementado em slides. Para, não depender, somente de textos (matemáticos ou na linguagem vernácula) utilizamos, também, a mesa digitalizadora.

A edição foi realizada utilizando software livre ${ }^{10}$. O que foi considerado excesso foi retirado e o tempo de cada vídeo não ultrapassou vinte minutos. Os vídeos foram criados na extensão . $w m v$ e foram inseridos na plataforma.

No Edpuzzle acrescentamos as interações previstas nos scripts: (a) questões abertas ou fechadas; (b) acrescentar comentários de áudio ou textual; (c) opção "Prevent Skipping" que impede ao estudante de pular partes do vídeo; (d) dentre outros. E, então, a metodologia foi implementada e o teste avaliativo 2 estava pronto. Criamos uma sala virtual, de modo, a compartilhar com os discentes. Nesta sala virtual, os vídeos do teste avaliativo 2 foram nomeados como parte A, B, C e D, conforme apresentado na figura.

9 Para as construções gráfica e de regiões utilizou-se o software livre geogebra 2D. Disponível online em: https://www.geogebra.org/graphing?lang=pt

10 Não há pretensão de indicar software de edição, pois compreendemos que um software para edição é algo particular de cada um. Para tal no link: https://filmora.wondershare.com.br/video-editor/ free-video-editing-software-windows.html?ftr=vidpgurl\&gclid=Cj0KCQjwg7KJBhDyARIsAHrAXa ExUhJMVak6qJhd9laK1maNcsQzuRYHTF1TsSkjbeFGkSSotCz2jGIaAnRMEALw_wcB o leitor encontrará mais de oito opções de softwares livres que poderá utilizar para editar vídeos. 
Figura 2: Teste avaliativo 2 - sala virtual Edpuzzle

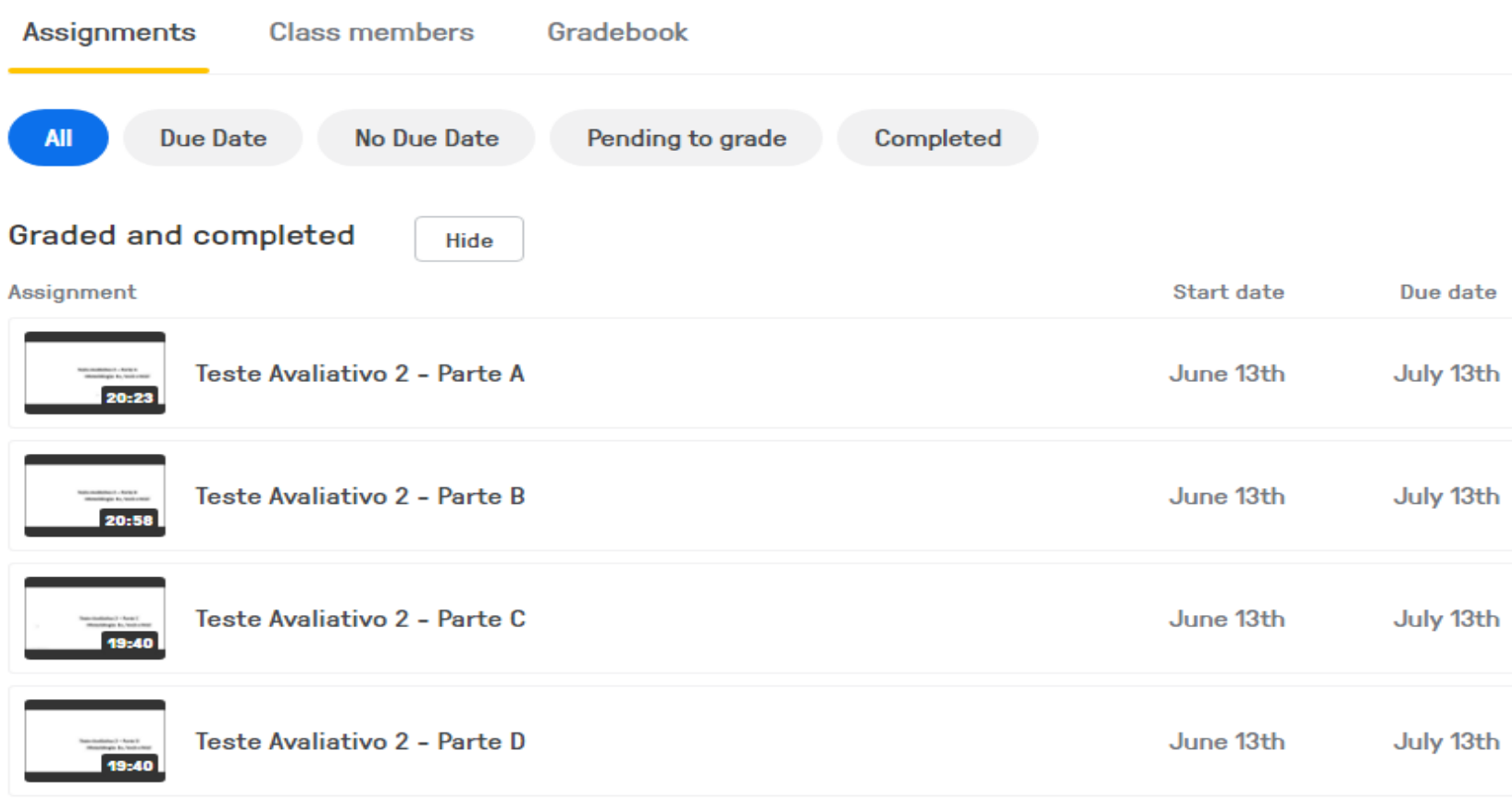

Fonte: Os autores (2021)

O link da sala foi disponibilizado aos discentes por e-mail.

\section{APLICAÇÃO DA ESTRATÉGIA E REFLEXÕES}

Ao abrir o primeiro vídeo, o discente foi apresentado a estratégia criada para a avaliação/construção/ampliação de seus conhecimentos. Ademais, os critérios de avaliação e os recursos que poderia/deveria utilizar também estavam revelados.

Logo, o primeiro passo - o EU - era executado. O docente resolvia um exercício para revisar e/ou construir conhecimentos sobre o método de integração. Importante salientar a relevância deste primeiro passo, uma vez que, na modalidade ERE, durante o encontro síncrono, discentes podiam ter dificuldades. Elas, por exemplo, poderiam estar relacionadas à concentração, conexão dos recursos tecnológicos (internet não satisfatória, participação por tela de smartphone, falta de acesso à comunicação por áudio, dentre outros), o que pode afetar a compreensão/construção de conhecimentos neste momento síncrono. 
Assim, entendemos que o primeiro passo propicia aos discentes uma autogestão da sua aprendizagem (PERREAUDEAU, 2009), em o (re) trabalho com variados aspectos. Dentre eles, destacamos: [a] realizar o teste avaliativo 2 no momento que julgar mais pertinente/adequado à sua aprendizagem; [b] concentração, uma vez que é somente o discente e o vídeo interativo; [c] anotações sobre detalhes outrora passados desapercebidos; [d] retroceder a explicação, [e] a experiência no tempo do discente. Desta forma, apresentamos um exemplo do momento mencionado trabalhado no método de integração por substituição na figura 3 .

Figura 3: Primeiro passo da estratégia aplicado ao método de substituição

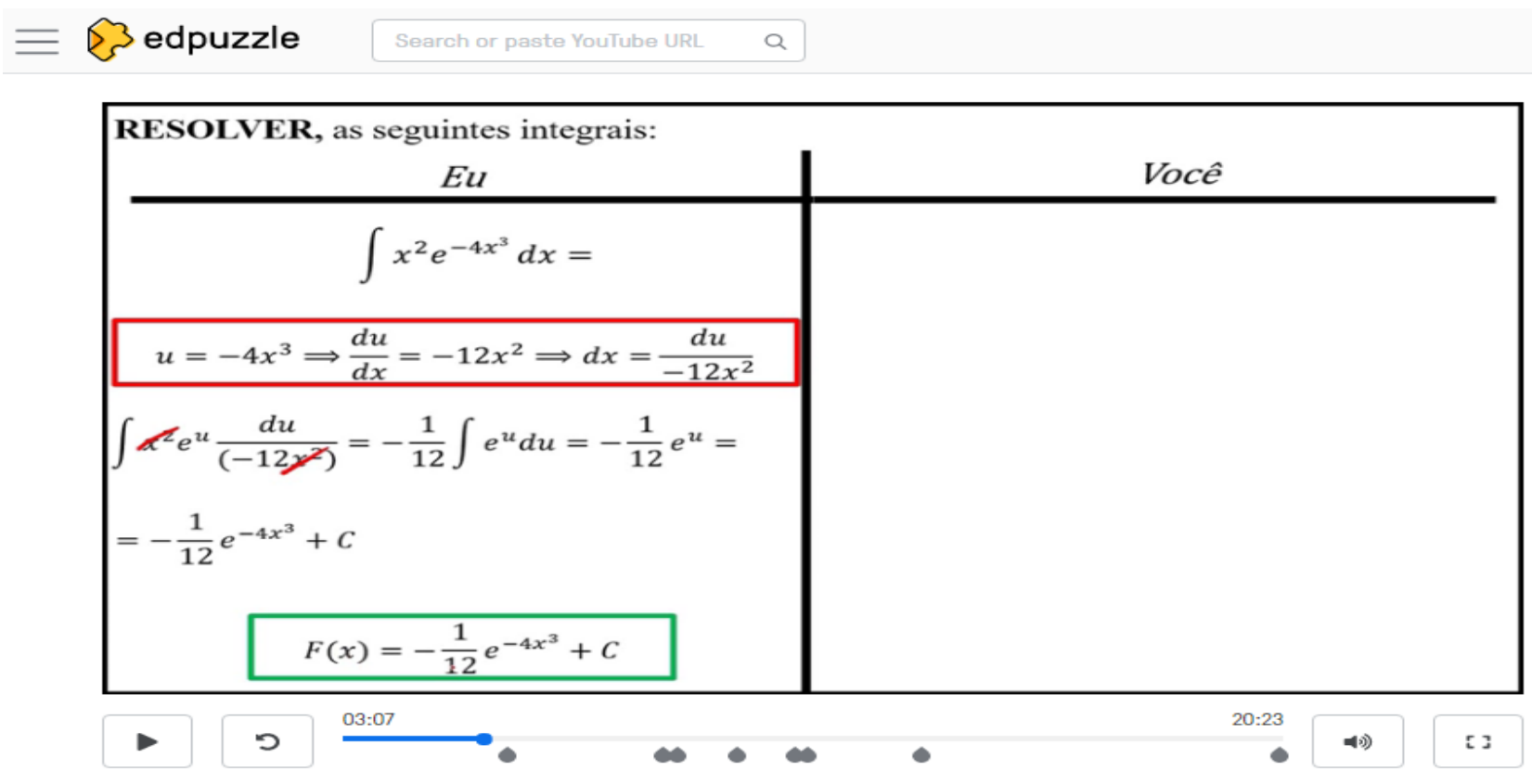

Fonte: Os autores (2021)

Se pode observar na linha de tempo do vídeo, os marcos em formato de "gotas". Eles são interações por meio de: [i] textos complementares (notes), [ii] áudios e/ou [iii] questões (abertas ou fechadas). Em tais marcos, o vídeo "congela" e a interação é apresentada ao discente. Ele, por sua vez, tem a possibilidade de ampliar o vídeo, retrocedê-lo e nivelar o som. Entretanto, o adiantar do vídeo foi bloqueado pelo docente no momento da implementação/edição. Outro fator interessante do Edpuzzle é que durante o vídeo, caso o discente mude de tela, ele pausa automaticamente. 
O segundo passo - o VOC $\hat{\mathbf{E}}$ - o discente foi convidado a resolver um exercício análogo utilizando o método trabalhado no primeiro passo. Uma interação era apresentada neste período (uma questão aberta ou fechada, uma nota explicativa ou áudio) que aparecia em tela. $\mathrm{O}$ vídeo pausava automaticamente e ele, neste momento, tinha a opção de retorná-lo em até doze segundos. Porém, não tinha opção de avançá-lo ou pular a questão.

A liberação do vídeo só ocorria após ele apresentar o seu resultado. Neste contexto, uma vez que o discente acabara de conhecer/revisar, no primeiro passo, um método que pode ser utilizado para a resolução da questão proposta ao mesmo, talvez a questão solicitada não se configure num problema, e sim num exercício (POZO, 2008). Na figura 4 apresentamos o segundo passo relativo ao método de integração por substituição relacionado ao primeiro passo supracitado. Veja que a ideia é que ambos os passos fiquem na mesma tela do vídeo, de modo a auxiliar o discente na construção de conhecimentos.

Figura 4: Primeiro e segundo passo da estratégia empregada - método substituição

\section{$\equiv$ B edpuzzle \\ $\leftarrow$ Video Preview}

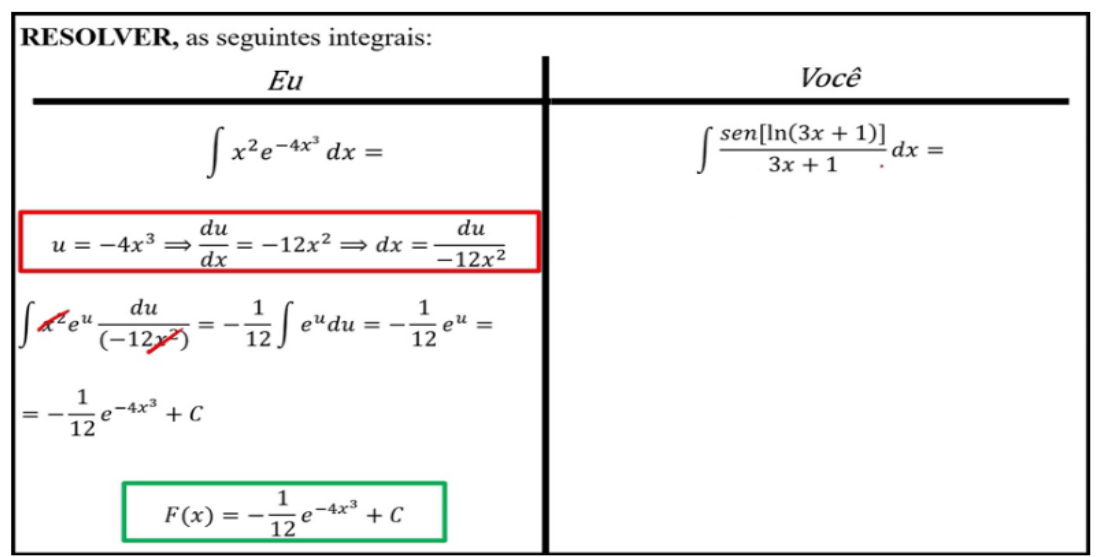

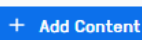

a Pri

Fonte: Os autores (2021)

A interação, além da explicação no primeiro passo, ocorreu neste segundo passo por meio de uma questão de múltipla escolha. Como mencionado, o lápis e o papel não foram abandonados durante este processo. Uma sugestão ao docente, é que as resoluções de questões podem ser solicitadas digitalizadas e salvas em arquivo PDF, o discente pode 
ser convidado a encaminhar por e-mail e/ou na plataforma que a instituição utilize. Assim o docente pode realizar comparações/avaliações detalhadas entre o que foi realizado no Edpuzzle e o que foi entregue.

Após marcar uma das opções, o vídeo era liberado. Por compreender que a aprendizagem, na modalidade ERE (ARRUDA, 2020; SANTOS et al., 2020), é potencializada por "feedbacks" (GAUTHIER et al., 2006), o docente gravou a resolução da questão do segundo passo, para que o discente pudesse "em tempo real" comparar a sua resolução com a resolução gravada/comentada do docente.

Importante salientar que na ferramenta é possível inserir "feedbacks" nas alternativas das questões fechadas. Todavia, o docente escolheu o feedback por meio de uma resolução comentada.

Figura 5: "Feedback" após a resposta do discente ao segundo passo

\begin{tabular}{|c|c|}
\hline $\begin{array}{l}\text { RESOLVER, as seguintes integrais: } \\
E u\end{array}$ & Você \\
\hline $\int x^{2} e^{-4 x^{3}} d x=$ & $\int \frac{\operatorname{sen}[\ln (3 x+1)]}{3 x+1} d x=$ \\
\hline$u=-4 x^{3} \Rightarrow \frac{d u}{d x}=-12 x^{2} \Rightarrow d x=\frac{d u}{-12 x^{2}}$ & $u=\ln (3 x+1) \Rightarrow \frac{d u}{d x}=\frac{3}{3 x+1} \Rightarrow d x=\frac{(3 x+1) d u}{3}$ \\
\hline $\begin{array}{l}\int x^{2} e^{u} \frac{d u}{\left(-12 \not^{2}\right)}=-\frac{1}{12} \int e^{u} d u=-\frac{1}{12} e^{u}= \\
=-\frac{1}{12} e^{-4 x^{3}}+C\end{array}$ & $\begin{array}{l}\int \frac{(3 x \not 1) \operatorname{sen}(u) d u}{3(3 x / 1)}=\frac{1}{3} \int \operatorname{sen}(u) d u= \\
=-\frac{1}{3} \cos (u)=-\frac{1}{3} \cos [\ln (3 x+1)]+C\end{array}$ \\
\hline$F(x)=-\frac{1}{12} e^{-4 x^{3}}+C$ & $G(x)^{*}=-\frac{1}{3} \cos [\ln (3 x+1)]+C$ \\
\hline
\end{tabular}

Fonte: Os autores (2021)

Deste modo, os dois primeiros passos eram realizados. Com o avançar dos vídeos, contextualizações/aplicações eram também trabalhadas nestes passos.

O terceiro passo - NÓS - geralmente trazia uma questão mais elaborada (situação-problema/aplicação do método trabalhado nos dois primeiros passos). Era o momento 
em que o docente e discente, ao mesmo tempo, resolviam a situação proposta. Para tal, o docente explicava até certo ponto a questão. E, então, surgia uma pergunta aberta solicitando a resolução pelo discente.

Caso ele tivesse alguma dificuldade em algum ponto da resolução, poderia escrever no espaço indicado os dizeres - "preciso de uma dica" - e submeter. O vídeo, então, prosseguiria com a continuação da resolução da situação-problema até certo ponto e uma nova questão aberta aparecia na tela para o discente.

A ideia supracitada, "pedir dicas", foi elaborada pelo docente, devido as limitações do Edpuzzle. Tais dizeres inicias deste texto indicam que a docência permite criatividade para a melhor organização dos recursos pedagógicos (TARDIF, 2015; GAUTHIER et al., 2006). Na figura 6 apresentamos o contexto descrito nos parágrafos supracitados referente ao terceiro passo da estratégia aplicada ao método de integração por substituição ${ }^{11}$.

Figura: Terceiro passo sendo executado - o Nós

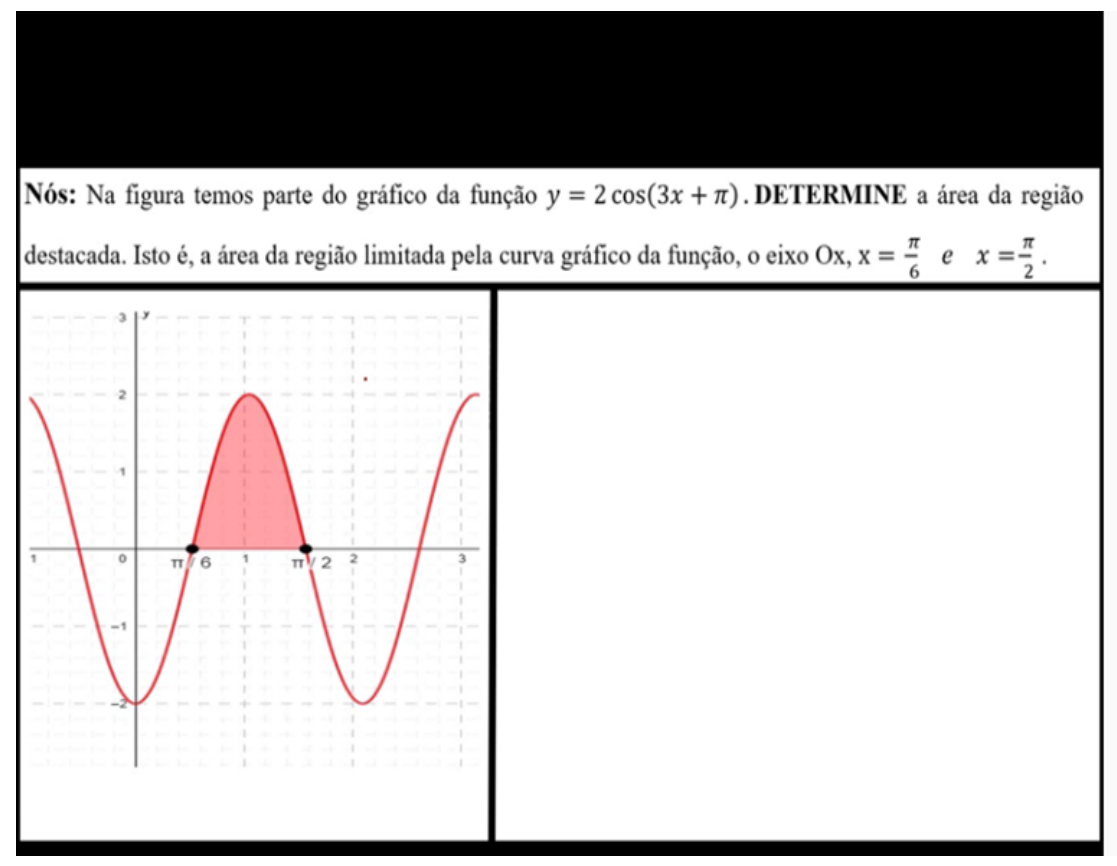

E) OPEN ENDED QUESTION

Caro estudante APRESENTE,

aproximadamente, a área calculada!

Caso não tenha conseguido ESCREVA:

"preciso de uma dica".

Rewatch

Fonte: Os autores (2021)

A situação-problema é uma aplicação clássica de integral definida - cálculo de área de uma região limitada por curvas. Nela, a integral a ser determinada é resolvida pelo método de integração por substituição. Sendo assim, o discente é convidado a passar

11 As figuras apresentadas neste texto foram extraídas do ambiente Edpuzzle do docente. 
da linguagem natural presente no enunciado para a linguagem matemática (representação da situação por uma integral definida). A questão aberta diz: "Caro estudante, APRESENTE aproximadamente, a área calculada! Caso não tenha conseguido ESCREVA: "preciso de uma dica"”.

O discente que de imediato obtivesse a área aproximada submeteria a sua resposta e o vídeo prosseguiria com os "feedbacks" gravados até na próxima questão aberta com os mesmos dizeres anteriores. Lembrando que no início do vídeo há uma explicação de que quanto menos "dicas" se pedisse maior a pontuação na questão (cada dica solicitada na avaliação final questão era descontado $10 \%$ como mencionado anteriormente neste texto).

A correção das questões abertas é realizada pelo próprio docente no Edpuzzle e o discente só recebe a pontuação final das questões do vídeo quando o professor disponibilizar. Além disso, durante a correção é possível o encaminhamento de feedbacks escritos aos discentes. Do mesmo modo, por ser uma questão aberta, o discente pode pedir a dica e relatar sobre a sua dificuldade no exato momento relativo à resolução da questão.

Figura 7: Após a solicitação de dica - método de integração por substituição

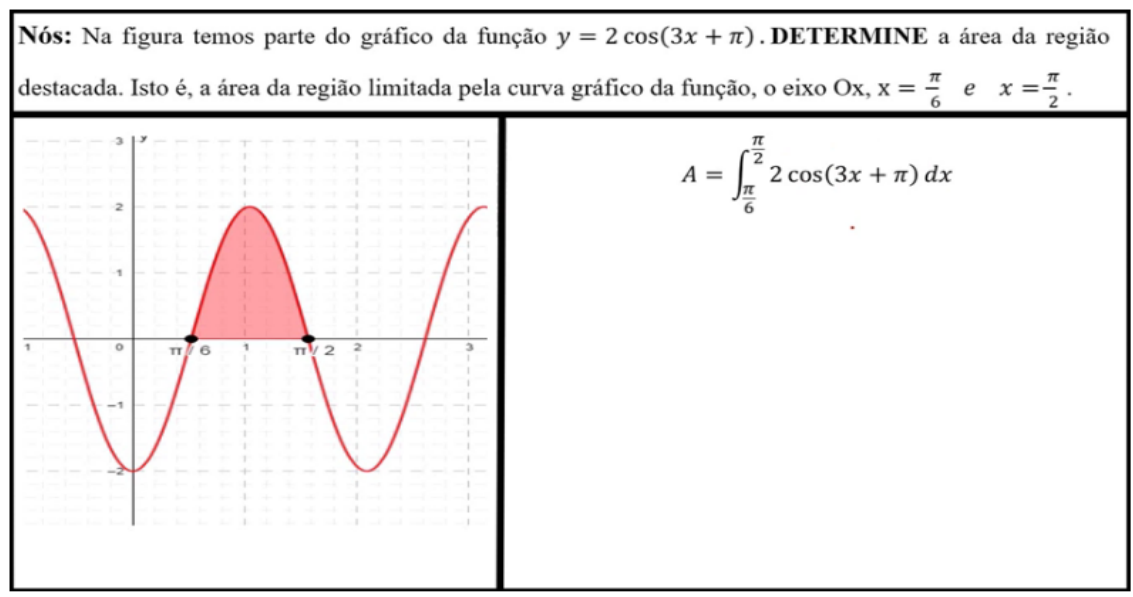

OPEN ENDED QUESTION

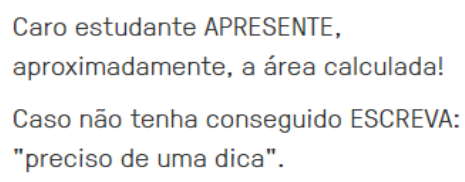


O objetivo do teste avaliativo 2 era de avaliar o discente em todo o contexto e percurso de aprendizagem. Deste modo, caso ele pedisse todas as dicas referente a questão, ao final do processo do terceiro passo era solicitado ao mesmo uma resposta dissertativa: "Caso tenha pedido todas as dicas! Lembre-se que o importante é construir conhecimentos! Você compreendeu a resolução desta questão? Deixe o seu comentário!".

A partir desta resposta dissertativa, o docente avaliava a questão no conceito restante a questão. Importante mencionar que a carga de trabalho docente é aumentada, porém, o retorno na questão da aprendizagem e no compartilhamento e apoio às dificuldades são potencializados.

Figura 8: Terceiro passo com o findar de todas as dicas

Bedpuzzle

+ Add Content

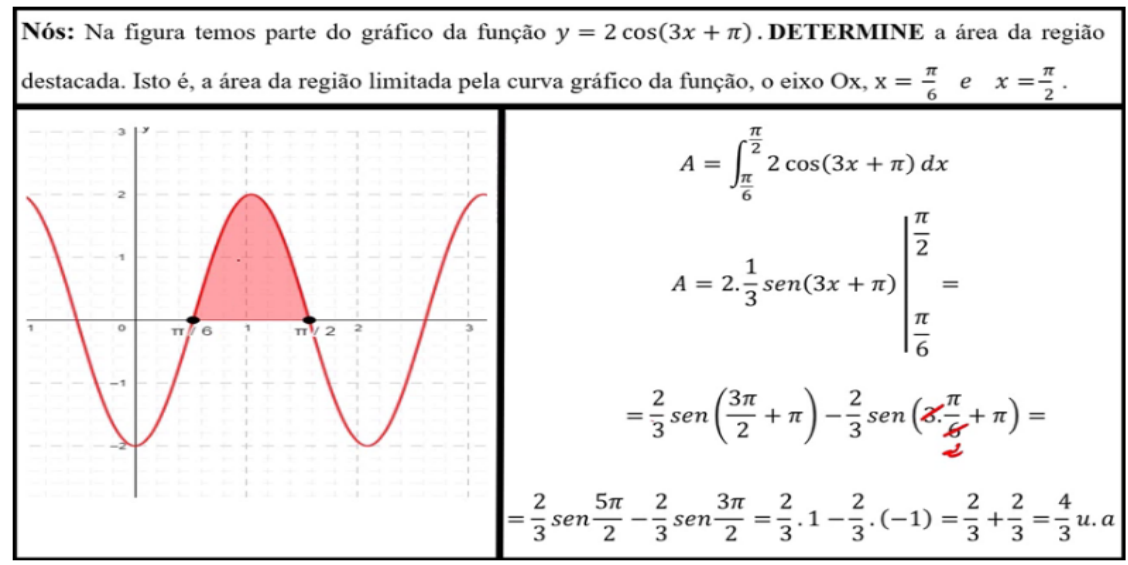

E OPEN ENDED QUESTION

Caso tenha pedido todas as dicas! Lembre-se que o importante é construir conhecimentos! Você compreendeu a resolução desta questão? Deixe o seu comentário!

Rewatch

Fonte: Os autores (2021)

Salientamos aqui que, na modalidade ERE, o avaliar exige um desafio contínuo, principalmente, na confiança da relação docente/discente. É dizer, que o discente irá realizar a parte que lhe cabe com ética, dedicação e comprometimento (SANTOS, 2014). Lembrando que aqui, apresentamos uma possibilidade de uma atividade avaliativa, porém, não é e não foi a única a ser aplicada na disciplina em questão.

Como mencionado, ao se avançar na realização do teste avaliativo 2, no primeiro ou segundo passo, foi proposto/solicitado a resolução de situação-problema/aplicação do método de integração abordado/trabalhado. 
Figura 9: Situação-problema/aplicação referente ao método de integração por partes

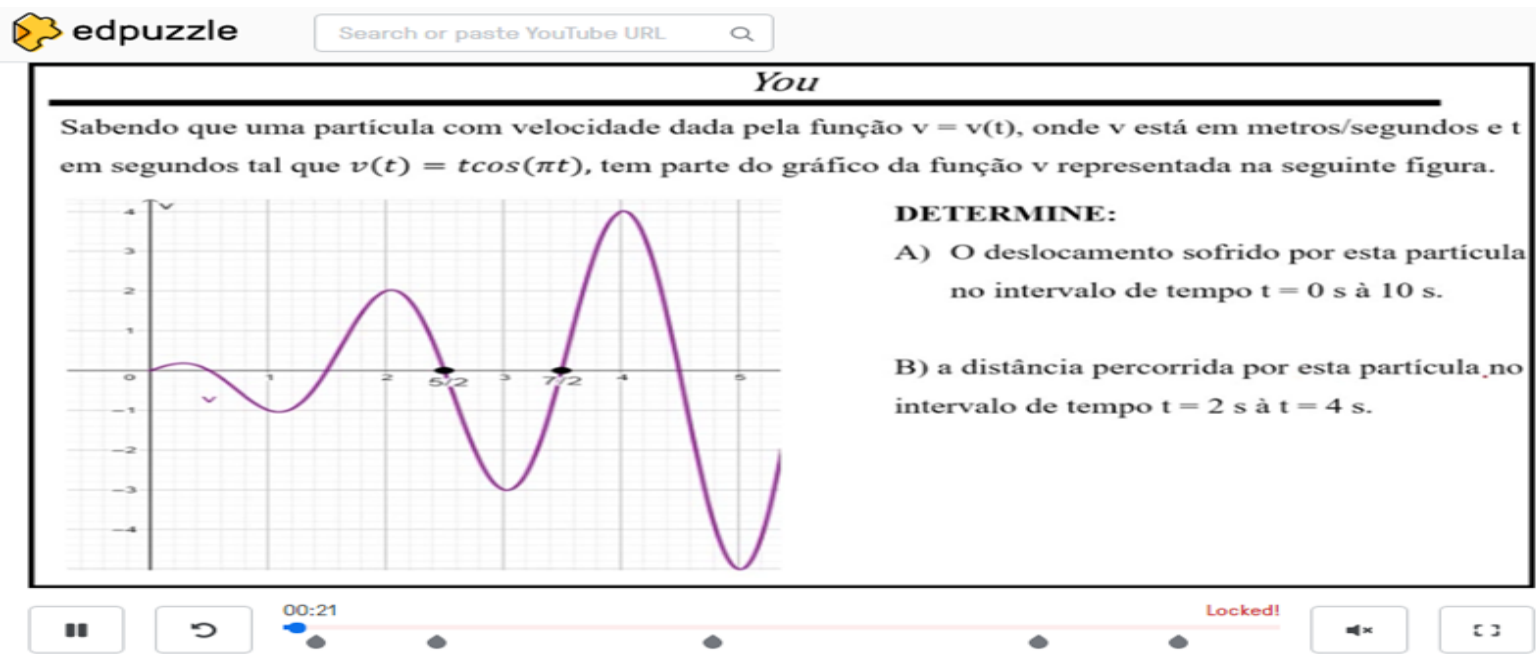

Fonte: Os autores (2021)

Para auxiliar o discente no segundo passo, quando o mesmo trazia questões de aplicação, chances extras para responder a situação proposta eram fornecidas tais possibilidades. Retomamos que, inicialmente se solicitava a resolução do discente e após o mesmo inserir sua resposta, o vídeo prosseguia com o feedback docente. Em certo momento, os dizeres em tela: "Caso não tenha conseguido inicialmente tente mais uma vez! Caso já tenha conseguido coloque o valor encontrado novamente! Caso queira mudar o valor colocado anteriormente, tudo bem!'. Vejamos a figura 10:

Figura 10: Possibilidade de reavaliar a resolução por parte do discente
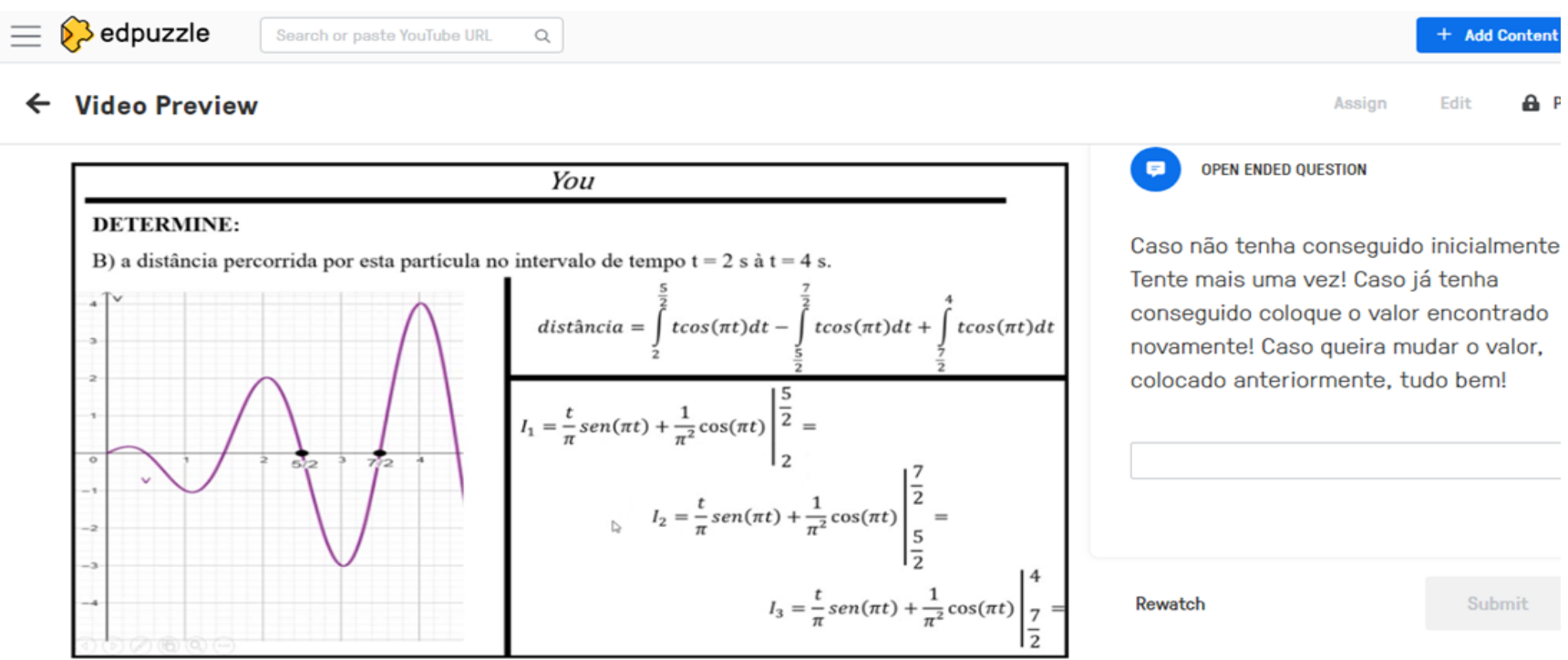

Fonte: Os autores (2021) 
Oferecer tal possiblidade foi um fator benéfico aos discentes que realmente levaram a sério a sua construção de conhecimentos por esta estratégia. Após chances de reavaliar a sua resposta, eles assistiam toda a resolução (feedback). Observemos a figura 11:

Figura 11: Feedback gravado para a situação-problema proposta no segundo passo para o método de integração por partes

\begin{tabular}{|c|c|}
\hline distância $=\int_{2}^{\frac{5}{2}} t \cos (\pi t) d t-\int_{\frac{5}{2}}^{\frac{7}{2}} t \cos (\pi t) d t+\int_{\frac{7}{2}}^{4} t \cos (\pi t) d t=$ \\
\hline$I_{1}=\frac{t}{\pi} \operatorname{sen}(\pi t)+\left.\frac{1}{\pi^{2}} \cos (\pi t)\right|_{2} ^{\frac{5}{2}}=\frac{5 \pi-2}{2 \pi^{2}}$ & distância $=\frac{5 \pi-2}{2 \pi^{2}}-\left(-\frac{6}{\pi}\right)+\frac{2+7 \pi}{2 \pi^{2}}=$ \\
$I_{2}=\frac{t}{\pi} \operatorname{sen}(\pi t)+\frac{1}{\pi^{2}} \cos (\pi t) \mid \begin{array}{l}\frac{7}{2} \\
\frac{5}{2}\end{array}=-\frac{6}{\pi}$ & $=\frac{12 \pi}{2 \pi^{2}}+\frac{6}{\pi}=\frac{6}{\pi}+\frac{6}{\pi}=\frac{12}{\pi}$ metros $\cong 3,82$ metros. \\
$I_{3}=\frac{t}{\pi} \operatorname{sen}(\pi t)+\frac{1}{\pi^{2}} \cos (\pi t)$ & $\mid \begin{array}{l}\frac{7}{2} \\
\frac{7}{2}\end{array}$
\end{tabular}

Fonte: Os autores (2021)

Reiterando a proposta, destacamos que a estratégia perpassou pelos métodos de integração mencionados neste texto. Utilizando os recursos e as interações relatadas. Para tal, foram necessários quatro vídeos de aproximadamente vinte minutos. $\mathrm{O}$ tempo dos vídeos partiu da premissa de que vídeos muito longos poderiam contribuir ao desânimo, a dispersão, dentre outros fatores por parte dos discentes.

Para a realização dos quatro vídeos, os discentes tiveram um mês de prazo. Podendo realizar o vídeo [1] em uma semana, o vídeo [2] em outra ou no melhor modo organizacional para potencializar a sua aprendizagem. Porém, deveriam ser assistidos na ordem indicada.

Além dos recursos supracitados, o Edpuzzle permite a criação de salas virtuais, a opção "Gradebook" - livro de notas - de cada vídeo assistido na sala criada. A nota é calculada de acordo com a implementação de questões abertas e fechadas (sempre avaliadas 
em 100) e então a média aritmética é realizada e convertida em uma única nota.

É possível fazer o download do Gradebook no formato de planilha. Ademais, é possível verificar o tempo que o discente gastou para concluir os vídeos. Destacamos que o vídeo pausa no momento das interações por questões. Logo, não necessariamente o discente gastará, neste caso, os vinte minutos do vídeo.

Figura 12: Partes do Gradebook do Teste Avaliativo 2 - Identificações Ocultadas

\section{Gradebook}

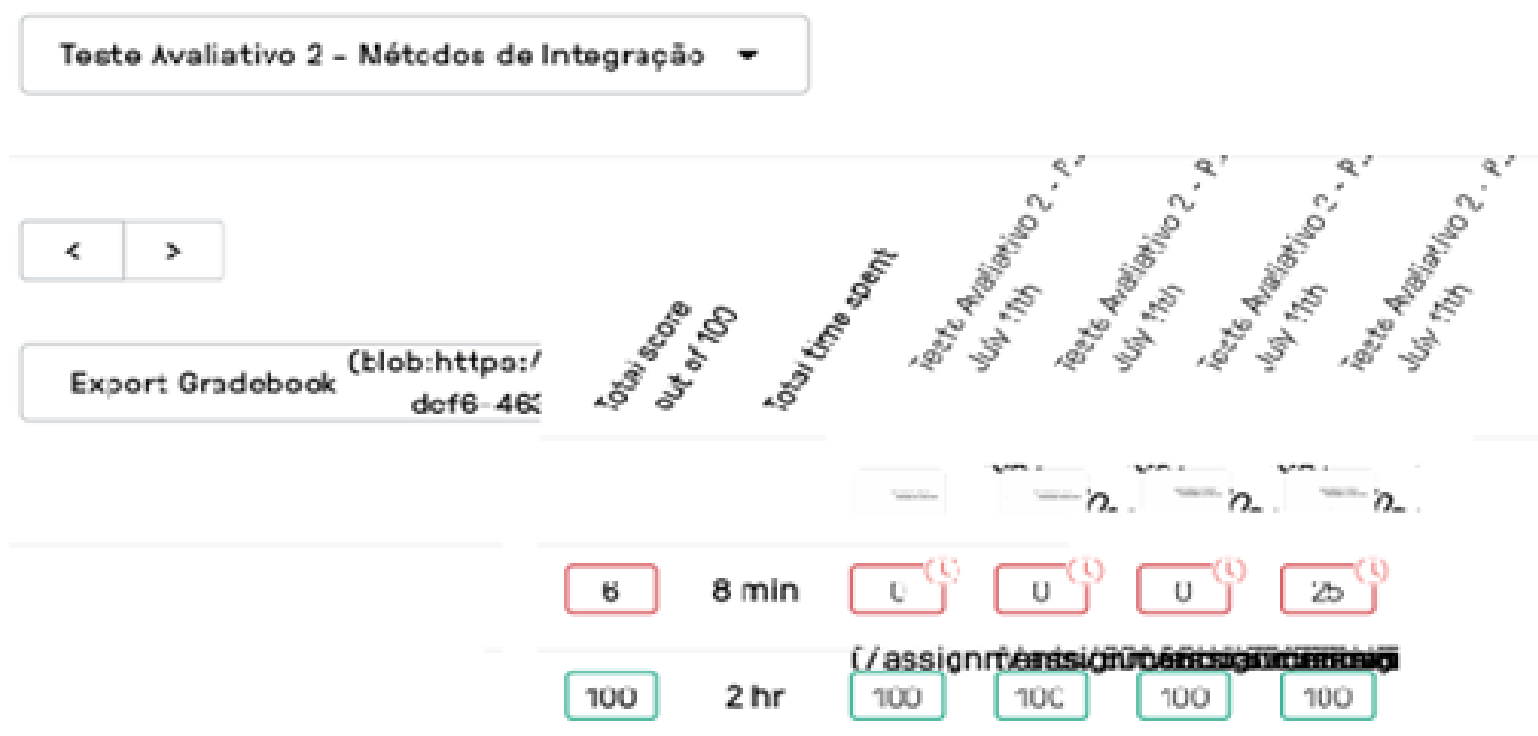

Fonte: Os autores (2021)

Como qualquer recurso, o Edpuzzle tem as suas limitações, a exemplo, na versão livre, é possível apenas utilizar vinte vídeos na pasta do docente. Caso o usuário queira hospedar o vigésimo primeiro vídeo deverá excluir outro. As interações são: questões (abertas/fechadas), áudio ou textuais. Porém, com criatividade a ferramenta contribui demasiadamente aos processos de ensino-aprendizagem.

Ao findar do teste, no quarto vídeo, foi proposta a questão aberta aos estudantes: "Caro estudante, com o findar do teste avaliativo 2, deixe os seus comentários a respeito do teste! Pontos positivos e pontos negativos! Críticas, sugestões elou elogios. COMENTE!". Esta questão, não foi obrigatória, e todos os discentes, mesmo não respondendo-a, ficaram com o conceito total. 
Figura 13: A última questão do teste avaliativo 2

$$
\begin{aligned}
& \begin{array}{|l|l|}
\hline A=\int_{1}^{3} \frac{x^{2}+2 x-1}{2 x^{3}+3 x^{2}-2 x} d x & \frac{x^{2}+2 x-1}{2 x^{3}+3 x^{2}-2 x}=\frac{A}{x}+\frac{B}{2 x-1}+\frac{C}{x+2}=\frac{1}{2 x}+\frac{1}{5(2 x-1)}-\frac{1}{10(x+2)} \\
\hline
\end{array} \\
& A=\int_{1}^{3} \frac{x^{2}+2 x-1}{2 x^{3}+3 x^{2}-2 x} d x=\int_{1}^{3}\left[\frac{1}{2 x}+\frac{1}{5(2 x-1)}-\frac{1}{10(x+2)}\right] d x= \\
& =\frac{1}{2} \int_{1}^{3} \frac{\mathrm{dx}}{\mathrm{x}}+\frac{1}{5} \int_{1}^{3} \frac{\mathrm{dx}}{2 \mathrm{x}-1}-\frac{1}{10} \int_{1}^{3} \frac{\mathrm{dx}}{\mathrm{x}+2}=\frac{1}{2} \ln |\mathrm{x}|+\frac{1}{5} \cdot \frac{1}{2} \ln |2 \mathrm{x}-1|-\left.\frac{1}{10} \ln |\mathrm{x}+2|\right|_{1} ^{3}= \\
& =\frac{1}{2} \ln |3|+\frac{1}{10} \ln |5|-\frac{1}{\not 0} \zeta \ln |5|-\frac{1}{2} \ln \left\langle\mathbf { 1 } ^ { \circ } | - \frac { 1 } { 1 0 } \operatorname { l n } | \left\{\left|+\frac{1}{10} \ln \right| 3 \mid=\right.\right. \\
& =\ln |3|\left(\frac{1}{10}+\frac{1}{2}\right)=\frac{3}{5} \ln |3| \text { u. a } \cong 0,6591 \text { u. a. } \\
& \frac{8}{10}: 2
\end{aligned}
$$

OPEN ENDED QUESTION

Caro estudante, com o findar do teste avaliativo 2, deixe os seus comentários a respeito do teste! Pontos positivos e pontos negativos! Críticas, sugestōes e/ou elogios! COMENTE!

Rewatch

Fonte: Os autores (2021)

Por meio desta questão aberta foi possível elaborar a próxima seção deste texto.

\section{RELATOS DOS DISCENTES A RESPEITO DA EXPERIÊNCIA - TESTE AVALIATIVO 2}

Para não identificar os discentes, suprimimos a identificação. Importante salientar que este trabalho se caracteriza como um relato de experiência. Nossa intenção não foi analisar em que medida esta estratégia contribui aos processos de ensino-aprendizagem ou a eficácia da ferramenta online Edpuzzle. Deste modo, os relatos exprimem o que fora solicitado - como foi a experiência durante a realização desta prática pedagógica. As respostas são apresentadas ao docente na ferramenta, conforme a figura 14 . 
Figura 14: Comentários discentes sobre o teste avaliativo 2

Sedpuzzle

Answers by students

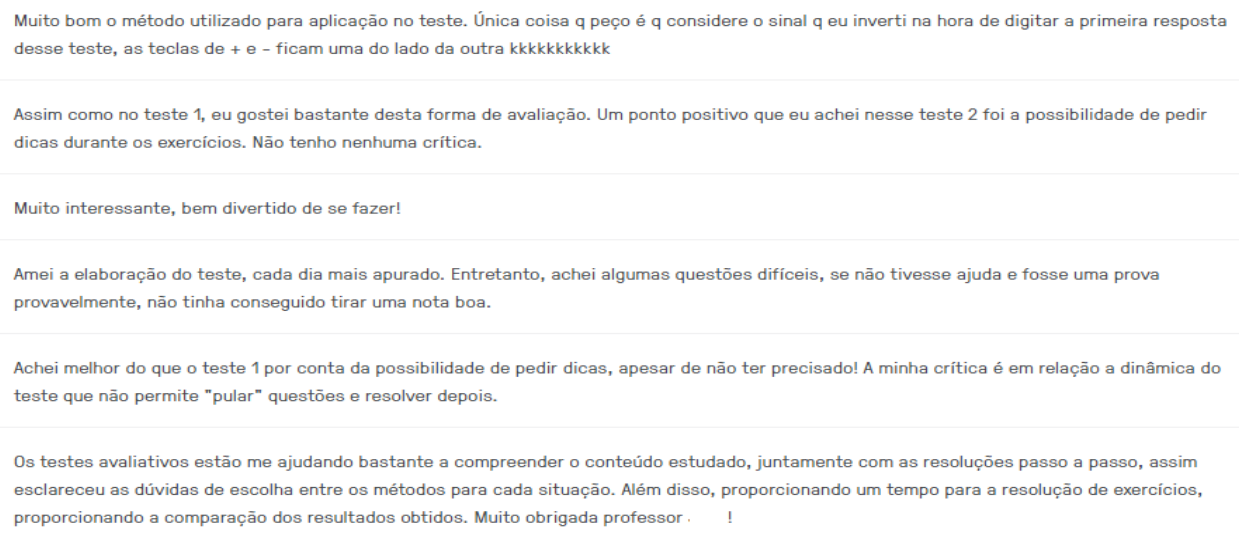

Fonte: Os autores (2021)

Para facilitar a leitura selecionamos algumas respostas e apresentamos no quadro 1. A primeira coluna é o comentário do discente e na segunda coluna uma pequena análise dos autores sobre o comentário. Vejamos:

Quadro 1: Alguns comentários da experiência

\section{Comentário do discente:}

Amei a elaboração do teste cada dia mais apurado. Entretanto achei algumas questões difíceis se não tivesse ajuda e fosse uma prova provavelmente não tinha conseguido tirar uma nota boa.

Achei muito interessante esse novo método de teste avaliativo gostei bastante [...]

Achei melhor do que o teste 1 por conta da possibilidade de pedir dicas apesar de não ter precisado! A minha crítica é em relação a dinâmica do teste que não permite "pular" questões e resolver depois."

\section{Análises dos autores:}

Parece que o auxílio, por feedback ou dicas, contribuiu a uma experiência positiva de aprendizagem. O discente nem reconheceu o teste avaliativo como uma prova.

O motivo pelo qual achou interessante e gostou não foi relatado.

Verifica-se que a possiblidade de amparo durante a realização do teste avaliativo tornou a experiência agradável. Relata-se também uma limitação da ferramenta utilizada. 
Achei o teste bem interessante pelo fato de passar por todos os métodos de integração e também apresentar exemplos sobre eles para reforçar a matéria “

O teste foi utilizado para revisar o conteúdo.

Como no primeiro achei a dinâmica bem legal!! Além de se fazer a avaliação retornamos a pontos importantes de tema. Assim como também relembramos conceitos que nos lembram dos aprendizados construídos em sala de aula.

Como dito no teste avaliativa 1 excelente estrutura de prova muito bem organizada e de fácil entendimento... consegui compreender ainda mais a matéria."

O teste além de oferecer a possiblidade de construção de novos conhecimentos funcionou como instrumento revisional.

O discente compreendeu que é um instrumento avaliativo. Porém, a experiência foi positiva, uma vez que, potencializou seus conhecimentos sobre as temáticas.

Muito criativo e a explicação antes dos exercícios ajuda DEMAIS" Os testes avaliativos estão me ajudando bastante a compreender o conteúdo estudado juntamente com as resoluções passo a passo assim esclareceu as dúvidas de escolha entre os métodos para cada situação. Além disso proporcionando um tempo para a resolução de exercícios $\mathrm{O}$ discente, reconheceu, quase que em suma o objetivo da estratégia criada. Aparentemente uma experiência exitosa e agradável.

proporcionando a comparação dos resultados obtidos.

Gostei agreguei conhecimento tenho que revisa e Foi possível a evolução, em algum nível, pratica uns métodos porém evolui muito. dos conhecimentos por parte do discente.

Fonte: Os autores (2021)

Os discentes que responderam tal questão demonstraram que o teste avaliativo 2 contribuiu a sua aprendizagem. Evidenciamos que nos quesitos de aprofundamento e revisão das temáticas, ampliação dos conhecimentos sobre a disciplina, dentre outros, foram aspectos revelados pela percepção discente. 
Como qualquer área profissional, a educação proporciona ao docente a criatividade e a formação continuada para elaborar novas estratégias e metodologias para contribuir aos processos de ensino-aprendizagem. Nesta perspectiva, entendemos que a utilização de vídeos pela ferramenta online Edpuzzle, demonstra introdutoriamente potencialidades a área do Cálculo Diferencial e Integral no contexto da educação superior.

\section{CONSIDERAÇÕES FINAIS}

Pensar nos processos de ensino-aprendizagem exigem dos profissionais da educação um esforço para poder buscar as melhores alternativas que possam contribuir para um avanço diante do contexto no qual se está presente. Na educação superior, por exemplo, a realidade não é diferente. Exige-se um compromisso com a formação, a trajetória do estudante e sua profissionalização para atuação nos diferentes espaços.

Neste sentido, quando trouxemos a experiência de uma prática pedagógica no contexto do Cálculo Diferencial e Integral, buscamos evidenciar possibilidades de como se pensar alternativas para qualificar a díade ensino-aprendizagem na educação superior. Além disso, destacamos que diante de um cenário inovador para a humanidade e para a área educacional, decorrente da pandemia da COVID-19, a busca por estratégias tecnológicas torna-se uma competência fulcral e necessária para o professor do século XXI.

Deste modo, a partir da estratégica didático-pedagógica "o Eu, o Você e o Nós" percebemos potencialidades para as relações educacionais em um contexto pandêmico. Além disso, identificamos que uma sequencialidade que alia o engajamento docente e discente e intenta aproximar tais agentes, de modo a qualificar as aprendizagens sobre os métodos de integração.

Evidenciamos que, a partir das sequências didáticas (scripts), tivemos a possibilidade de apropriarmos de um conhecimento tecnológico por meio da ferramenta online Edpuzzle e inovar as ações destinadas ao Cálculo Diferencial e Integral. Ademais, ficou revelado nos discursos discentes uma percepção positiva acerca da vivência realizada ao longo da disciplina e que ela possibilitou uma melhor compreensão sobre o conteúdo desenvolvido. 
À guisa de uma conclusão e pensando no contexto remoto, a estratégia “ $O E u, o$ Você e o Nós" buscou revelar a importância da autogestão do processo de ensino-aprendizagem e como é possível estabelecer, mesmo distanciados fisicamente, uma relação pedagógica integradora. Além disso, é perceptível que a estratégia poderá ser adaptada e aplicada também no contexto presencial, seja como instrumento complementar e/ou avaliativo. Por fim, também foi possível elucidar como essa prática pode ser pensada na educação superior. Logo, esperamos que este trabalho possa contribuir para a reflexão sobre as estratégias didático-pedagógicas em diferentes contextos, não somente para a área da Educação Matemática, mas para outros campos.

\section{REFERÊNCIAS}

ARRUDA, Eucidio Pimenta. Educação Remota Emergencial: elementos para políticas públicas na educação brasileira em tempos de Covid-19. EmRede - Revista de Educação a Distância, v. 7, n. 1, p. 257-275, 15 maio 2020.

BORBA, M. de C.; DOMINGUES, N. S. O Uso de Tecnologias em Aulas de Matemática Aplicada: vídeos em um ambiente de aprendizagem multimodal. In: Educação Matemática, Tecnologia Digitais e Educação a Distância: pesquisas contemporâneas. Org. ROSA, M.; BAIRRAL, M. A.; AMARAL, R. B. Ed: Livraria da Física. $1^{\mathrm{a}}$ ed. São Paulo. SP. 2015.

GAUTHIER, Clermont et al. Por uma teoria da Pedagogia. Trad. Francisco Pereira. 2. ed. Ijuí: Unijuí, 2006. 457 p.

PERREAUDEAU, Michel. Estratégias de aprendizagem: como acompanhar os alunos na aquisição dos saberes. Porto Alegre: Artmed, 2009.

POZO, Juan Ignacio. Aprendizes e Mestres. A nova cultura da aprendizagem. Porto Alegre: Artmed, 2008.

SANTOS, Guilherme Mendes Tomaz dos et al. Educação superior: reflexões a partir do advento da pandemia da COVID-19. Boletim de Conjuntura (BOCA), Boa Vista, v. 4, n. 10, p. 108-114, oct. 2020. Disponível em: https://revista.ufrr.br/boca/article/ view/Santos_et_al/3139. Acesso em: 25 oct. 2020. DOI: http://dx.doi.org/10.5281/zenodo. 4073037 . 
SANTOS, Guilherme Mendes Tomaz dos. O comprometimento do estudante e a aprendizagem em Cálculo Diferencial e Integral I. 217 f. Dissertação (Mestrado em Educação) - Universidade La Salle, Canoas, 2014.

TARDIF, Maurice. Saberes docentes e formação profissional. 14. ed. Petrópolis: Vozes, 2015. 


\section{SOBRE OS ORGANIZADORES}

\section{Guilherme Mendes Tomaz dos Santos}

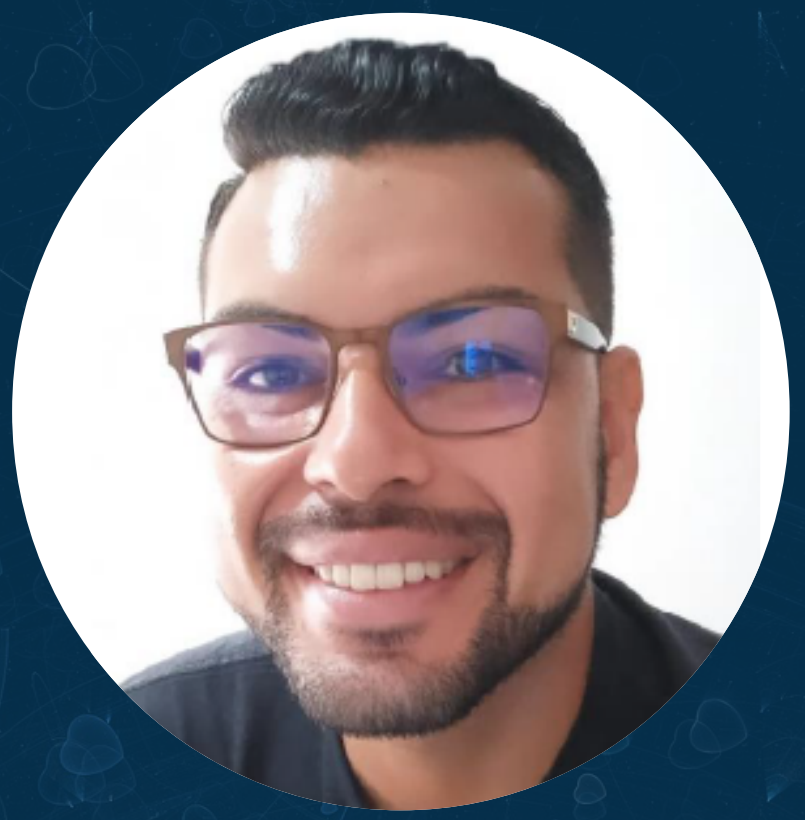

Pós-Doutorando pelo Programa de Pós-Graduação em Educação da Universidade Federal do Rio Grande do Norte (PPGEd/UFRN). Bolsista PNPD/CAPES. Doutor em Educação - área de Gestão, Educação e Políticas Públicas - (2018) pela Universidade La Salle (UNILASALLE/Canoas). Realizou Estágio de Pesquisa Doutoral na Direção de Pós-Graduação e Pesquisa e no Programa de Pós-Graduação em Educação da Universidad La Salle México (ULSA) em 2016/1 e 2017/1. Mestre em Educação - área de Formação de Professores, Teorias e Práticas Educativas - (2014) pela mesma instituição. Realizou período sanduíche (2014/1) na Universidad La Salle (ULSA/Cidade do México) na área de Intervenção Docente. Especialista em Supervisão Educacional (2014) e Educação Matemática (2021) pelo Centro Universitário Leonardo da Vinci, Graduação em Licenciatura Plena em Matemática (2011) pelo Centro Universitário Metodista IPA e Licenciatura em Pedagogia (2020) pelo Centro Universitário Internacional - UNINTER. Graduando em Direito pela Faculdade Maurício de Nassau (UNINASSAU). 


\section{Júlio Paulo Cabral dos Reis}

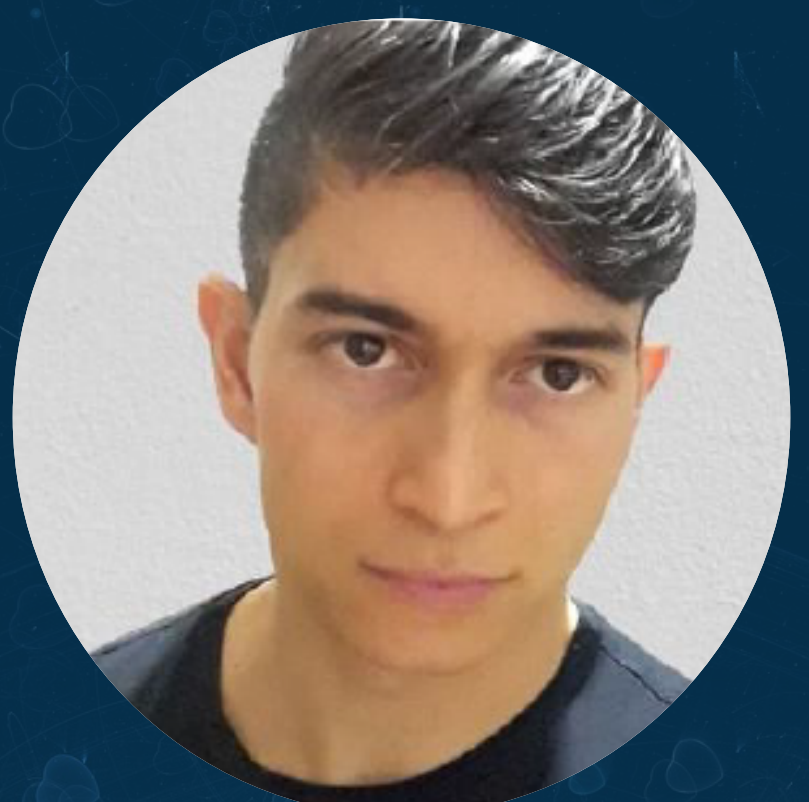

Possui graduação em Licenciatura Plena em Matemática (2009). Mestrado pelo Programa de Pós- Graduação em Ensino de Ciências e Matemática, ofertado pela Pontifícia Universidade Católica de Minas Gerais (2013). Atualmente é professor do Instituto Federal de Minas Gerais (IFMG) - Campus Ibirité. Integrante do Grupo de Pesquisa em Informática e Metodologia para o Ensino em Matemática - GRUPIMEM (PUCMinas). Linhas de pesquisa: Ensino e Aprendizagem de Cálculo Diferencial e Integral, Objetos de Aprendizagem (OA), Tecnologia da Informação e Comunicação, Inteligência Artificial e Resolução de Problemas. Tem experiência na área de Matemática do Ensino Básico e Matemática do Ensino Superior, com ênfase em Cálculo Diferencial, Integral e Numérico, Álgebra e Geometria. 
www.terried.com

contato@terried.com

@editora_terried (0)

leditoraterried 6

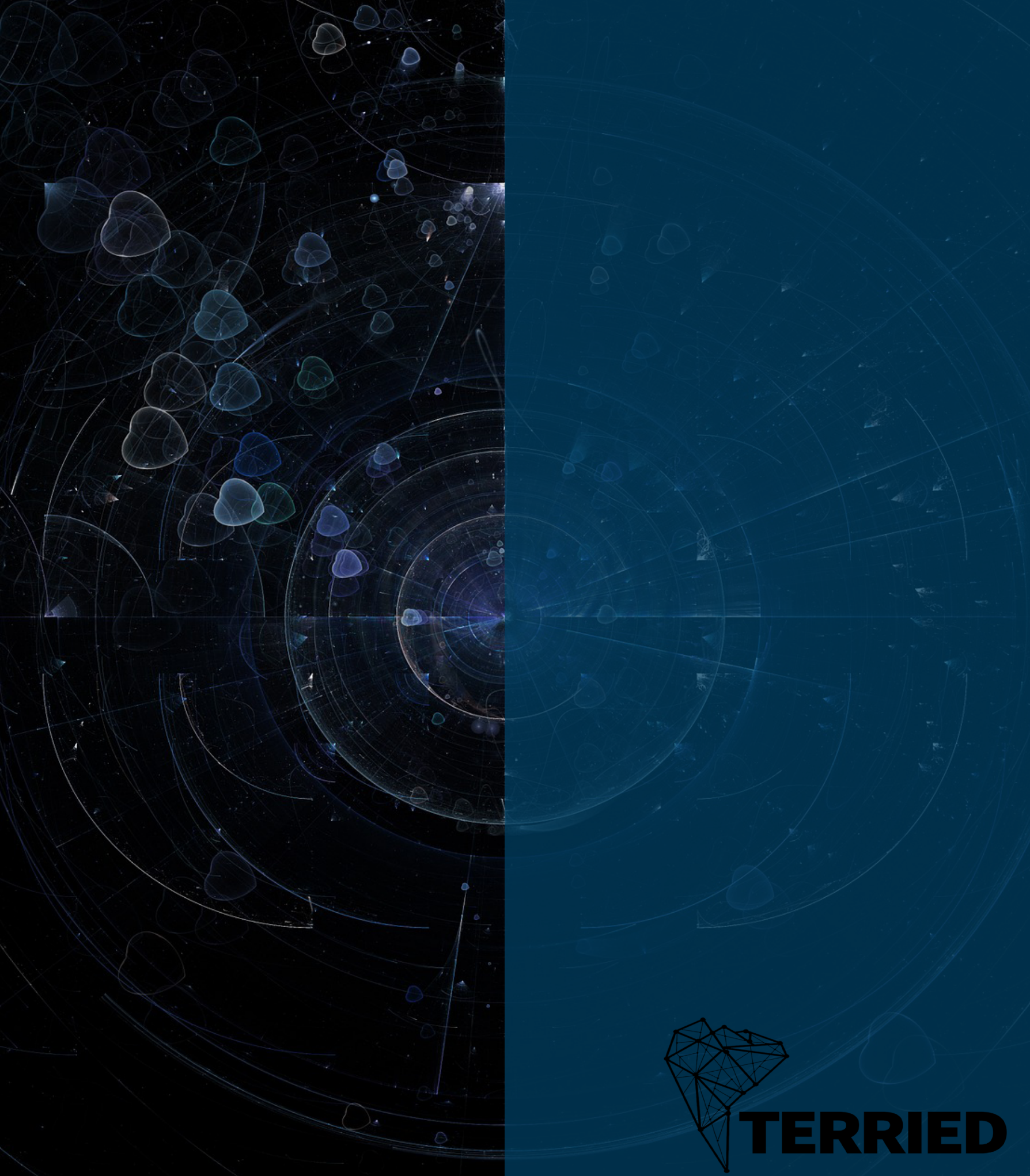

